Journal of Educational

and Psychological Sciences

Volume (6), Issue (10): 28 Feb 2022

P: 1 - 20

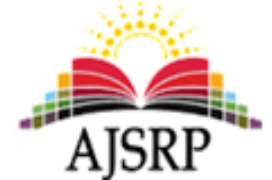

ISSN: 2522-3399

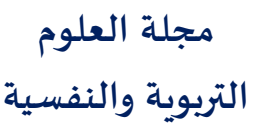

المجلد (6))، العدد (10): 28 فبراير 2022 م

ص: 1 - 10

\title{
The degree of practicing the motivational leadership by the public school principals in the capital Amman governorate and its relationship to Enhance the creativity culture among teachers from their point of view
}

\author{
Jehan Mohamad Shawqi Shamasneh \\ Ministry of Education || Jordan
}

\begin{abstract}
The study aimed to identify the degree of practicing the motivational leadership by the public school principals in the capital Amman and its relationship to promoting a culture of creativity among teachers From their point of view. A descriptive correlative survey method was used. A questionnaire was designed as a study tool, consisting of (28) items, and divided into five domains. It was distributed to a random stratified sample consisted of (360) teachers of public schools in Kasbah Amman district, and the university in the capital Amman governorate. The results of the study concluded that the degree of public school principals in the capital, Amman, of motivational leadership from the teachers' point of view, obtained a total average (3.86 out of 5), meaning a (high) degree of practice. Morale with an average of (3.93) and finally the administrative motivation with an average of (3.67), all of them with a degree of practice (high), and that the level of creativity culture among teachers in public schools in the capital Amman, from their point of view, came with a total average (4.16 out of 5), i.e. at a level (high) and at the level of the two areas; The flexibility field got an average of (4.25) with a rating of (very high), then the originality field with an average of (4.08) and the degree of availability (high) for the culture of creativity. Schools for motivational leadership and promoting a culture of creativity among teachers, and based on the results, the researcher recommended the need to encourage school principals to find new motivational strategies and methods that contribute to promoting a culture of creativity among teachers.
\end{abstract}

Keywords: Practicing Degree - School Principals - the capital Amman - Motivational Leadership - Promoting a Culture of Creativity.

$$
\text { درجة ممارسـة مديري المدارس الحكومية بالعاصيمة عمان للقيادة التحفيزية }
$$

\footnotetext{
المستخلص: هدفت الدراسة إلى التعرف على درجة ممارسة مديري المدارس الحكومية بالعاصيمة عمان للقيادة التحفيزية وعلاقتها بتعزيز ثقافة الإبداع لدى المعلمين من وجهة نظرهم، حيث استخدمت المنهج الوصفي المستحي الارتباطي، وتم تصهميم استبانة كأداة للدراسة

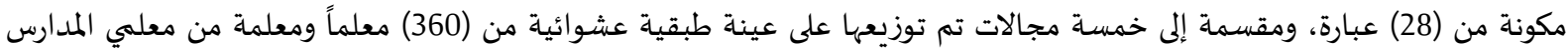

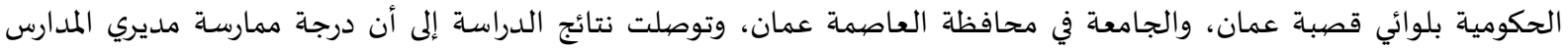
الحكومية بالعاصممة عمان للقيادة التحفيزية من وجهة نظر المعلمين قد حصلت على متوسط كلي لهيل (3.86 من 5) أي بدرجة ممارسة (مرتفعة)، وعلى مستوى المجالات حصل مجال التحفيز المهني على أعلى متوسط (3.98) ثم التحفيز المعنوي بمتوسط المهادئ (3.93) وأخيراً
} 


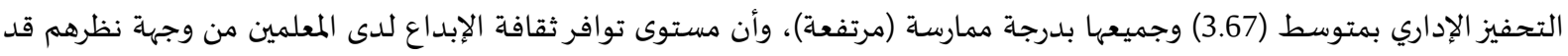

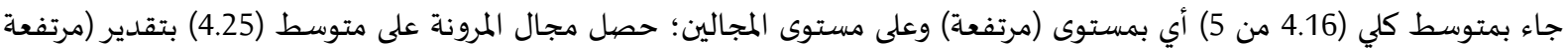

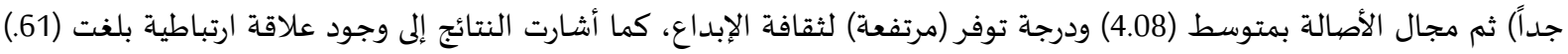

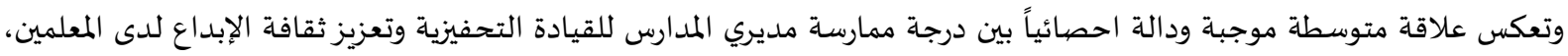

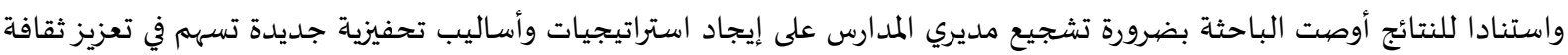
الإبداع لدى المعلمين.

الكلمات المفتاحية: درجة ممارسة-مديري المدارس-العاصمة عمان-القيادة التحفيزية-تعزيز ثقافة الإبداع.

المقدمة.

يعد المعلم المحور الرئيسي في العملية التعليمية، إذ يرتبط نجاحها وتقدمها بشكل كبير به، وهو الذي يقوم على إكساب الطلبة المعارف والمفاهيم والمعلومات الجديدة، لذلك فإن الاهتمام بالمعلم وتقديم الدعم له، ومساندته، ومساعدته على استثمار طاقاته وقدراته تعد قضية جوهرية بهدف الارتقاء بالعملية التعليمية وتحقيق تقدم المدرسة وتميزها، ولتحقيق ذلك لا بد من وجود قيادات مدرسية مؤهلة تتبنى الأساليب القيادية التي تؤثر بفاعلية وايجابية

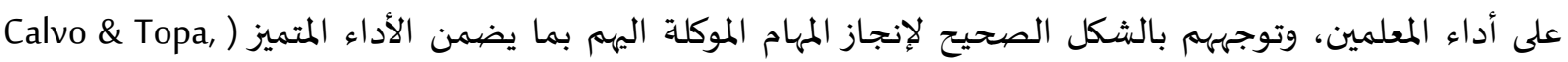

ويعد التحفيز أحد أهم أساليب القيادة الناجحة لتشجيع المعلمين، وتقديم أفضل ما لديهم، وتأدية مهامهم بكفاءة عالية، كما يسهم التحفيز في شحن همم المعلمين وتوجياه سلوكهم نحو الإنجاز وتحقيق الأهداف، فالتحفيز

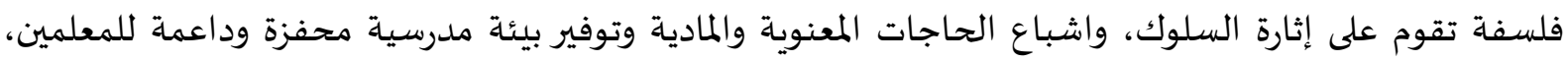

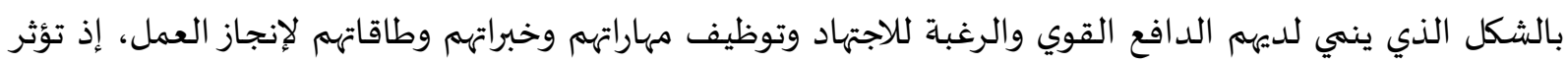

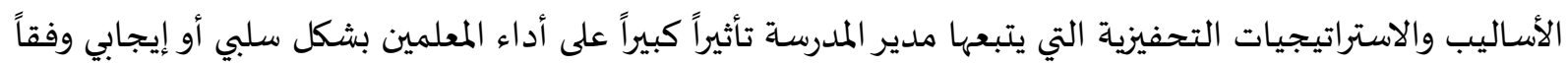

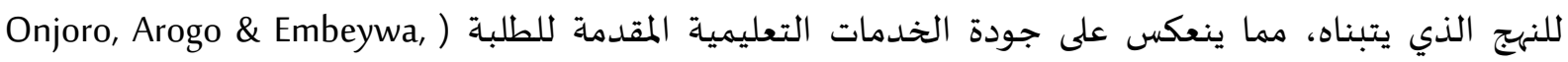

وتكمن أهمية القيادة التحفيزية كما أشار اليها كل من لوبيزوجروبستروم ( Lopez \& Grubbström, 2018 )

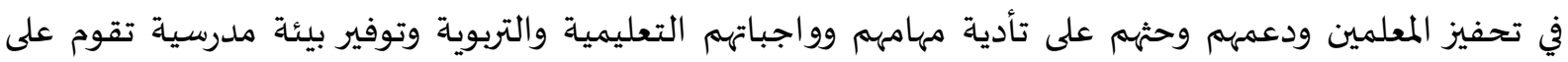

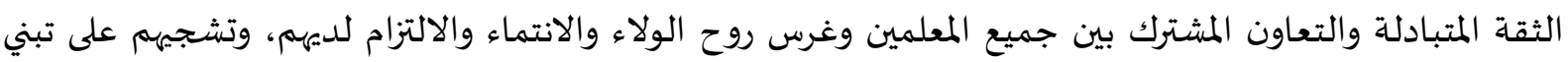

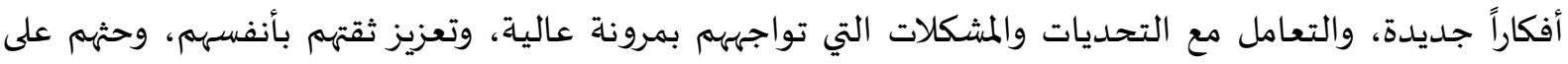

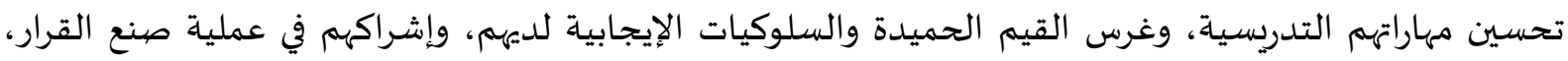

وتقديم الحوافز والمكافئات لهم، وتقليل العقوبات المفروضية عليهم (Ahmad, Abbas, Latif \& Rasheed, 2014).

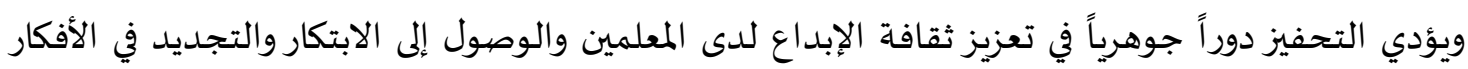

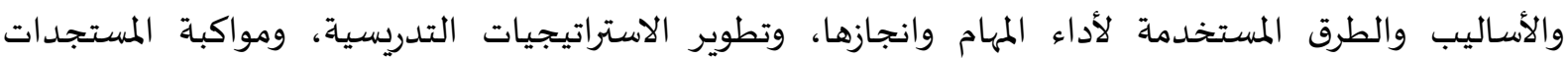

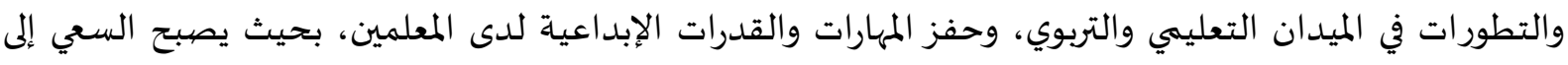

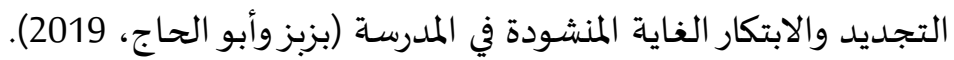

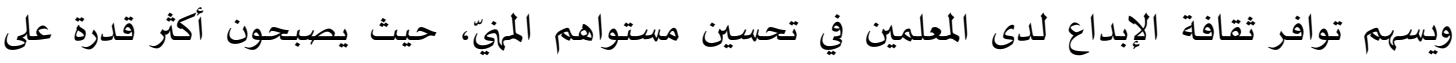

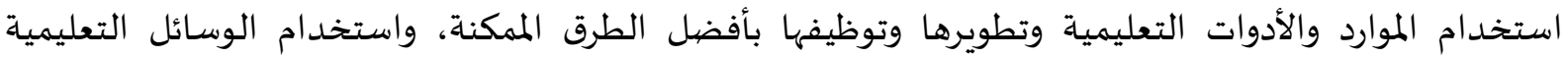

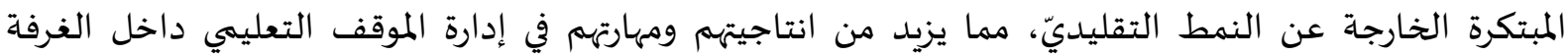


الصفية، وتحقيق التواصل الفعّال مع الطلبة، وبالتالي تحسين مستواهم التعليهيّ والثقافي ( Wibowo \& Saptono,

مشكلة الدراسة:

يعد تحفيز المعلمين في المدارس من القضايا الضرورية التي أصبحت لا غنى عنها في ظل التطور المتسارع في

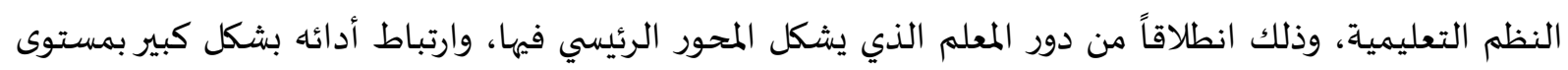

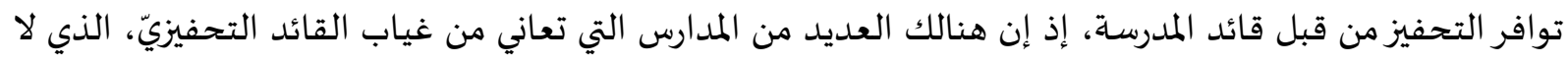

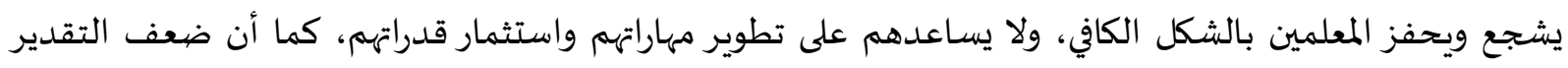

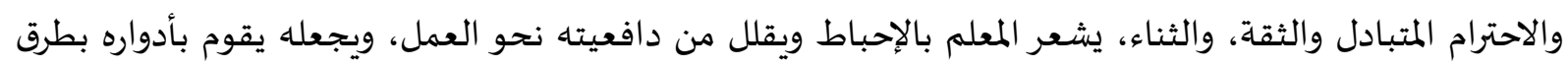

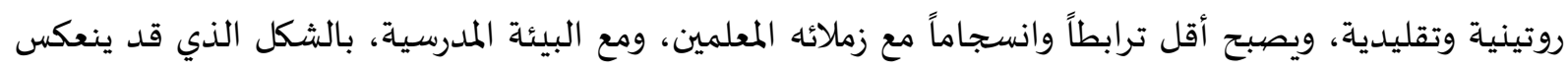

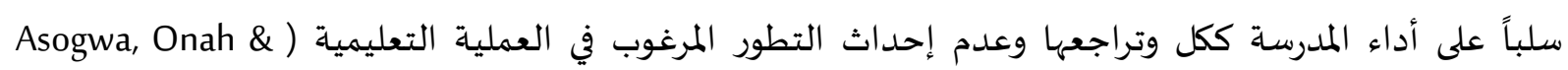

(Gideon, 2020

وتكمن مشكلة الدراسـة بأنه لا يزال العديد من مديري المدارس يتبعون الأنماط التقليدية في إدارة المدارس

ويتبعون المركزية في اتخاذ القرارات، ولا يوظفون الأنماط القيادية الحديثة التي تقوم على توجيه طاقات ملات المعلمين

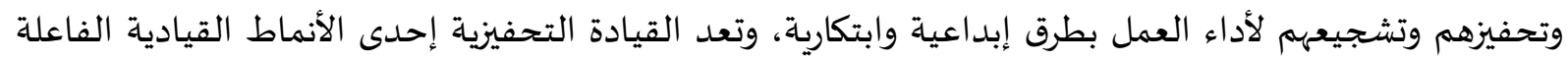

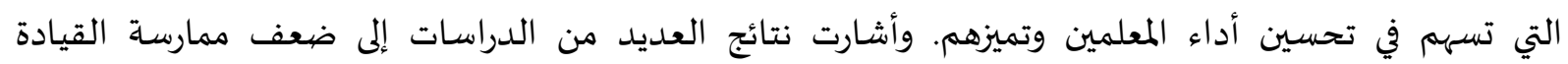

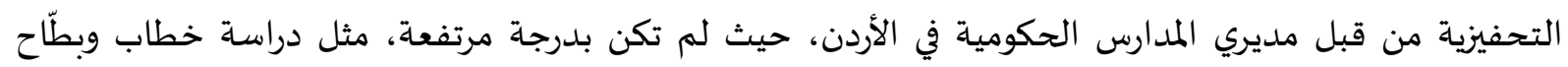

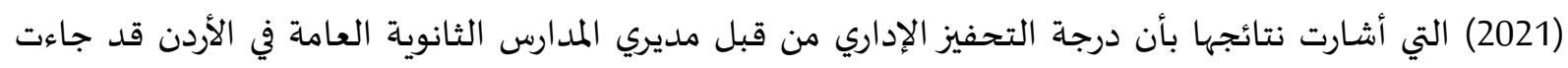

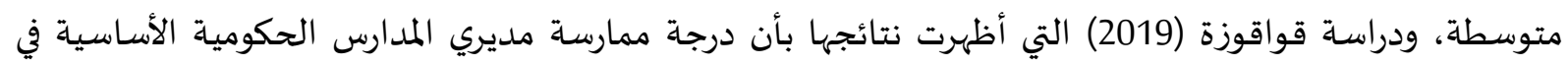
محافظة جرش لتحفيز المعلمين قد جاءت متوسطة، وبالتالي قد ينعكس ذلك على تراجع ثقافة الإبداع لدى الدى المعلمين،

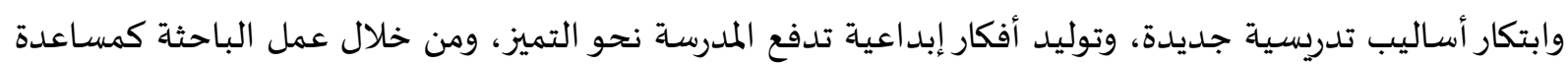

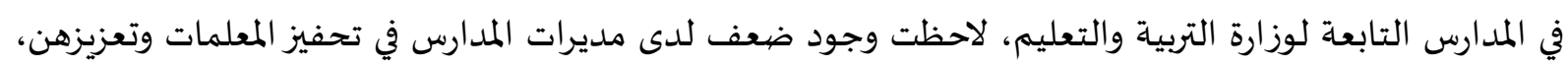

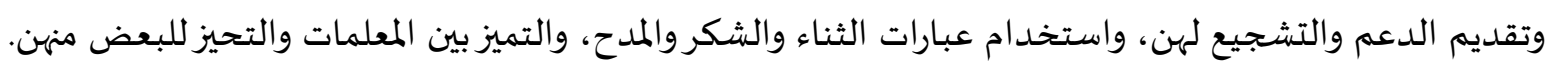

أسئلة الدراسة

تتحدد مشكلة الدراسـة في الأسئلة التالية:

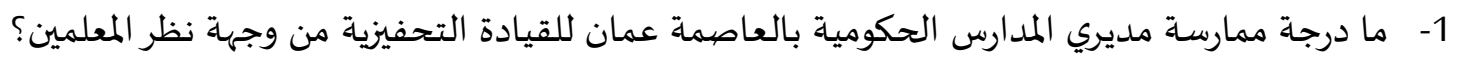

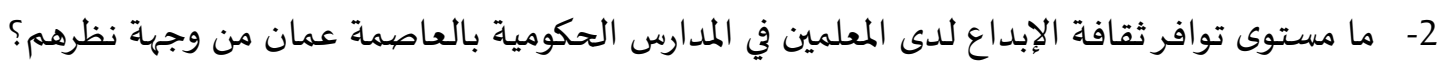

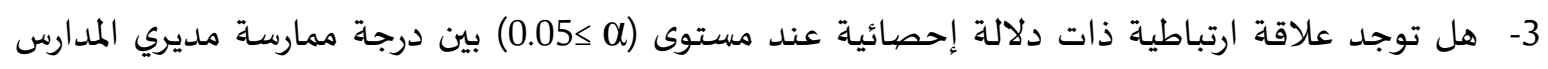

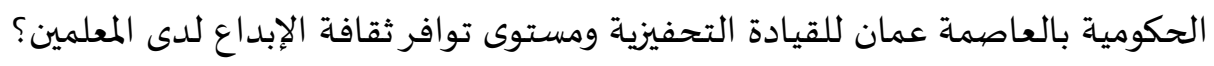

أهداف الدراسة

تتمثل أهداف الدراسة الحالية فيما يلي:

1- التعرف على درجة ممارسة مديري المدارس الحكومية بالعاصمة عمان للقيادة التحفيزية من وجهة نظر التراف

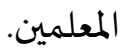


2- التعرف على مستوى توافر ثقافة الإبداع لدى المعلمين في المدارس الحكومية بالعاصمة عمان من وجهة نظرهم.

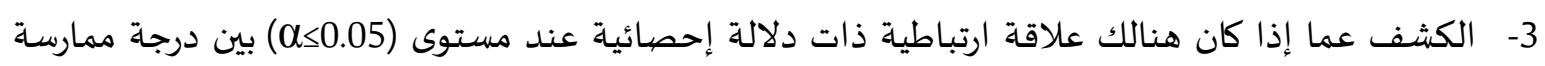
مديري المدارس الحكومية بالعاصممة عمان للقيادة التحفيزية ومستوى توافر ثقافة الإبداع لدى إدى المعلمين.

أهمية الدراسـة:

تكمن أهمية الدراسة الحالية بجانبيها النظري والعملي، على النحو الآتي:

الأهمية النظرية

ــندرة الدراسات والأبحاث التي ربطت بين موضوعي القيادة التحفيزية وثقافة الإبداع، إذ تعد هذه الدراسة

إضيافة نوعية جديدة على حد علم الباحثة.

- إثراء المكتبة الأردنية بشكل خاص، والمكتبة العبية بشكل عام بدام بدراسة تفتح آفاقاً أمام الباحثين والتربويين

لإجراء دراسـات أخرى مماثلة.

الأهمية التطبيقية:

يؤمل أن تفيد الدراسة الحالية وزارة التربية والتعليم في وضع برامج تدريبية تستهدف إعداد مديري المدارس

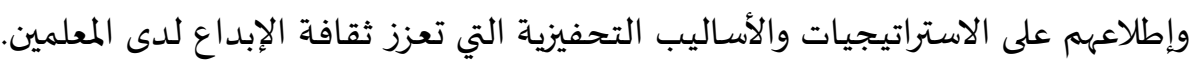
- من المتوقع أن تفيد هذه الدراسة مديري المدارس باطلاعهم على أهمية انتهاج نمط القيادة التحفيزية وأبرز صفات القائد التحفيزي من أجل تطبيقها داخل المدرسة.

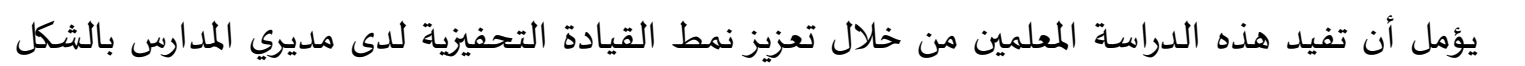
الذي ينعكس إيجاباً على تعزيزثقافة الإبداع لديهه.

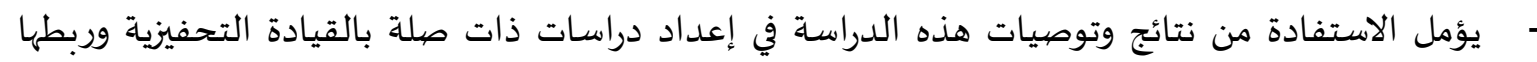
بمتغيرات أخرى في مجتمعات مختلفة.

حدود الدراسة

تتمثل حدود الدراسة بالآتي: الحدود الموضوعية: درجة ممارسة القيادة التحفيزية وعلاقتها بثقافة الإبداع. الحدود البشرية: المعلمين في المدارس الحكومية. الحدود المكانية: المدارس الحكومية بالعاصهمة عمان.

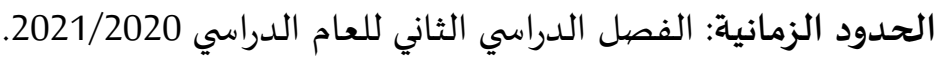

مصطلحات الدراسة:

تم تعريف مصطلحات الدراسة اصطلاحيا وإجرائياً على النحو الآتي:

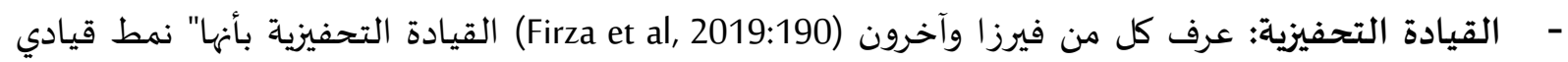
تحفيزي يقوم من خلاله القائد بحث الأفراد العاملين وتشجيعهم وغرس الدافعية لديهم، وتعزيز روح الونلاء

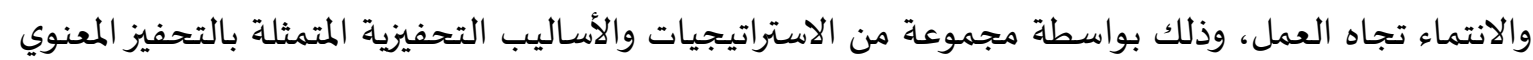

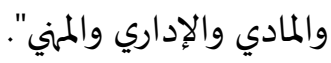


وتعرف القيادة التحفيزية بأها:" نمط من أنماط القيادة التي يتبعها القائد والتي تتميز بتوجه القائد نحو تحفيز

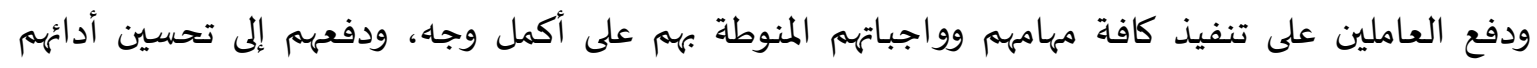

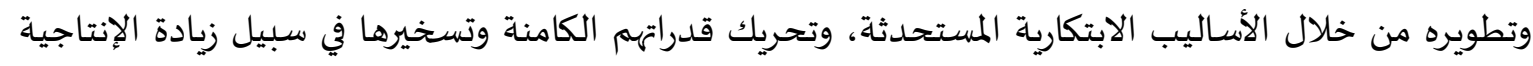

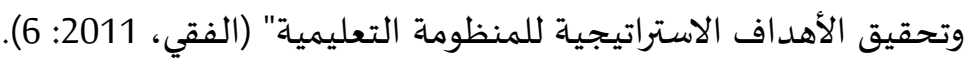
وعرف أحمد وآخرون (Ahmad et al, 2014:13 القيادة التحفيزية بأهها:" الأساليب والآليات التي يتبعها القائد

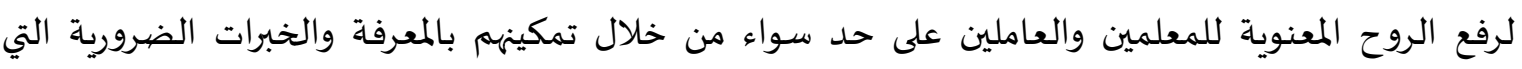
تساعدهم في تفجير طاقاتهم، وبذل جهود أكبر تنعكس بشكل إيجابي على المنظومة التعليمية ككل".

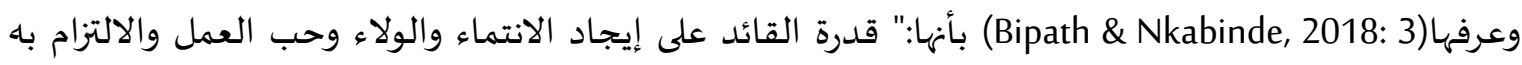

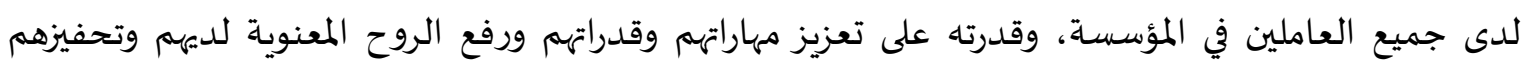
لتطوير خبراتهم والاستفادة منها في سبيل تحقيق أهداف المؤسسية".

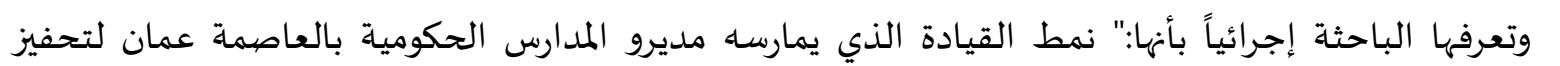

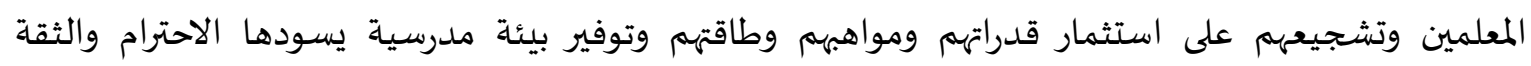

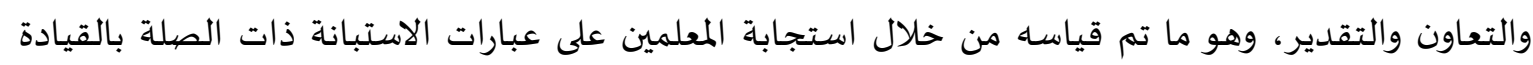

ثقافة الإبداع: عرف الفاخوري (2018: 139) ثقافة الإبداع بأنها: " ثقافة مرتبطة بقدرة الأفراد على توليد أفكار

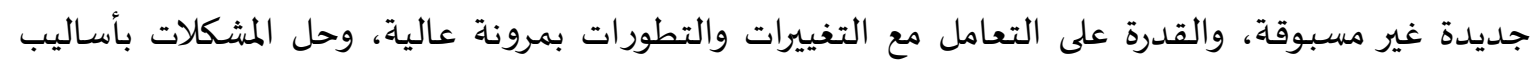
مبتكرة، وتمتع الأفراد بالأصالة والطلاقة والمرونة". ويعرف (Alawawdeh, 2016: 98) ثقافة الإبداع بأنها قدرة المعلمين على ابتكار أفكار ونظريات ورؤى وأشياء

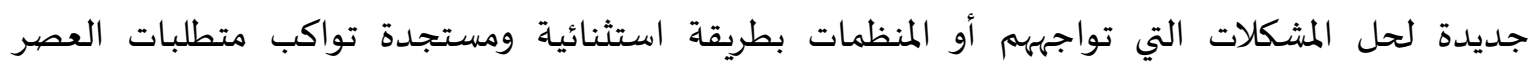
والتكنولوجيا الناشئة فيه. م وتعرف الباحثة ثقافة الإبداع إجرائياً بأها:" مدى إدراك معلمي المدارس الحكومية بالعاصهمة عمان للابتكار

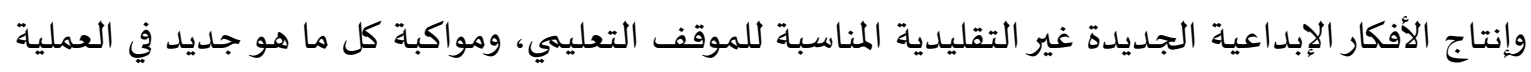

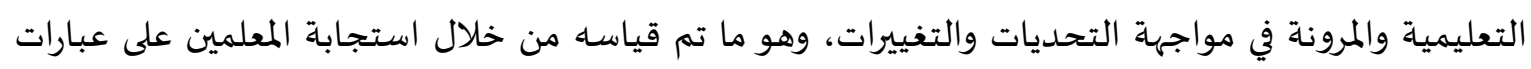
الاستبانة ذات الصلة بثقافة الإبداع".

2-الإطار النظري والدراسـات السـابقة. أولاً: الإطار النظري.

\section{أهمية القيادة التحفيزية:}

تعد القيادة التحفيزية أحدى أهم الأساليب والآليات في القيادة المدرسية لكونها تساهم في تمكين المعلمين

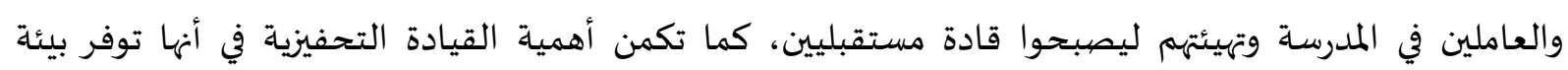

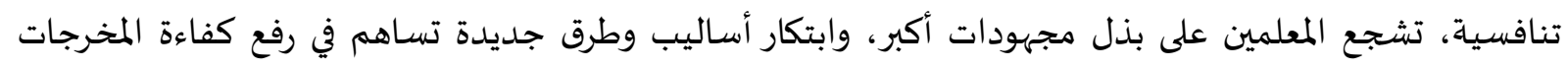

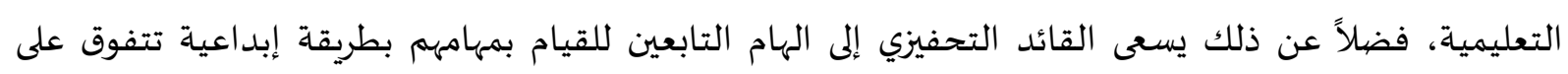

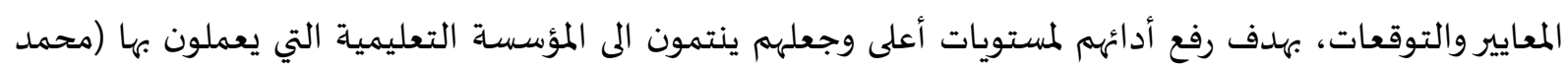
وآخرون، 2017). 
وتعد القيادة التحفيزية من أهم الأنماط القيادية القادرة على تحسين المخرجات في المؤسسات التعليمية، إذ إذ إناء

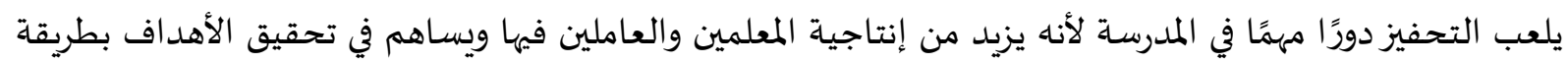
فعالة، فضلاً عن ذلك؛ يساعد القائد التحفيزي على تغيير سلوك المعلمين بشكل فئل إيجابي من خلال منال منحهم البيئة

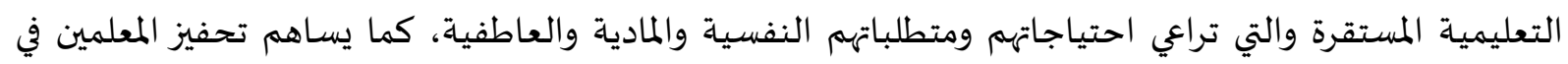

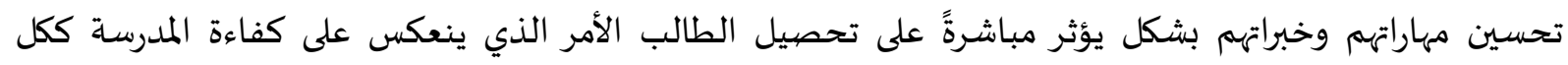
(الناطور، 2011).

ولأهمية التحفيز فقد أصبحت مسألة تحفيز المعلمين وضمان الجودة مسألة نقاش واهتمام في النظم

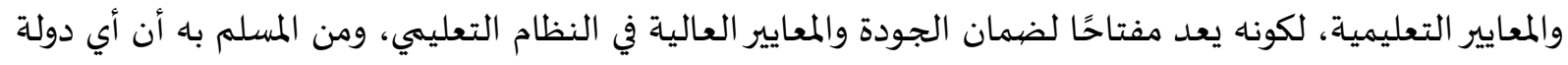

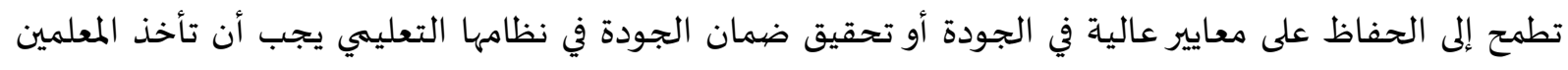

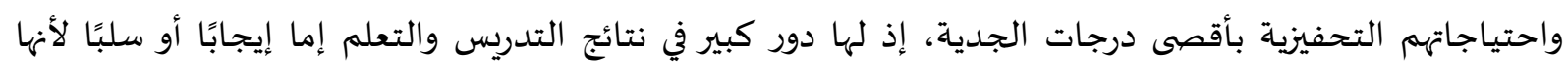
تحدد جودة تقديم التعليم فضلاً عن جودة تنفيذ المناهج والسياسات التعليمية (Calvo \& Topa, 2019).

\section{صفات القائد التحفيزي:}

يعد القادة المحفزون ذوو دوافع ذاتية، إذ يعون تماماً أهمية التحسين الشخصي والمهني المستمر للموظفين

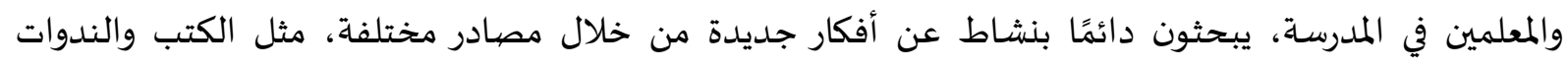

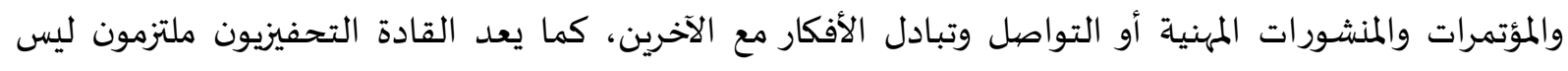

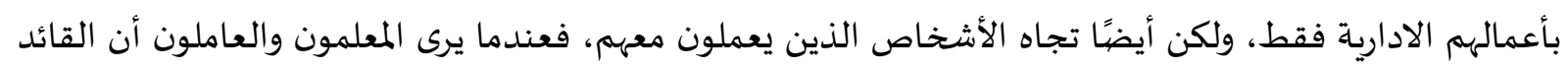

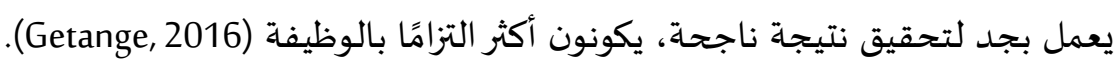

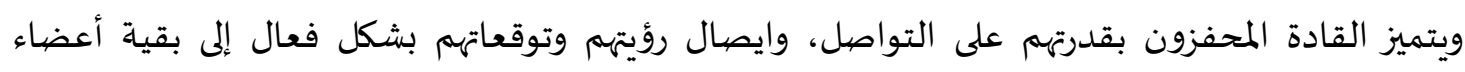

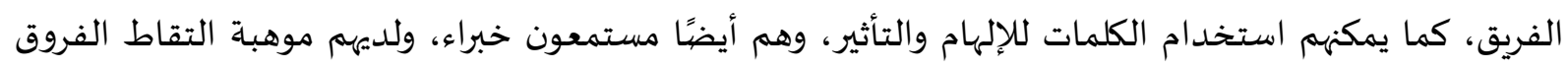

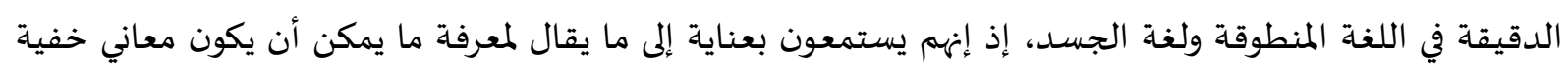
.(Lopez \& Grubbström, 2018)

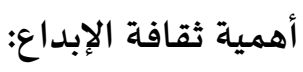
تعد ثقافة الإبداع لدى المعلمين أداة مهمة في تحسين مخرجات المؤسسات التعليمية وتجويدها، وتطوير

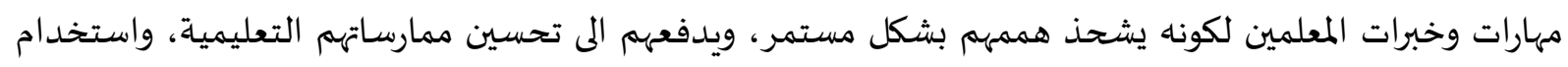

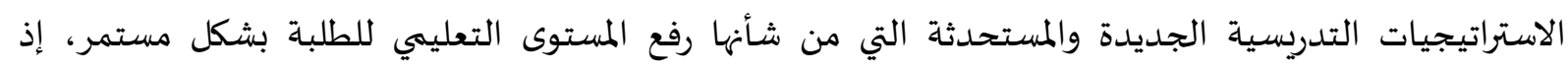
يساعد الإبداع على اكتشاف وصقل مهارات وقدرات الأفراد القائمين على العملية التعليمياة، وزيادة جودتهات العاديا ومرونتها.

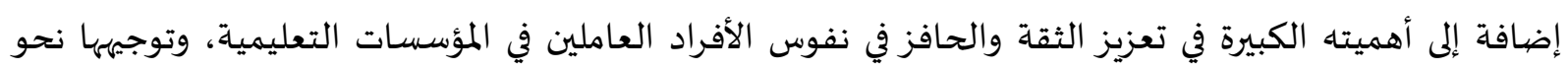
تطوير أساليب تدريسية جديدة تخدم العملية التعليمية وترفع من كفاءتها (Sutanto, 2017).

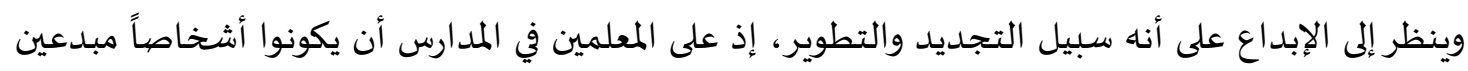

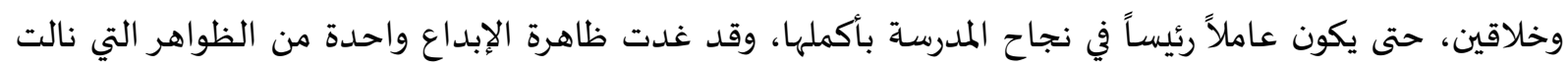

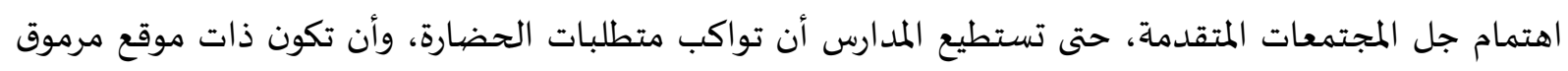

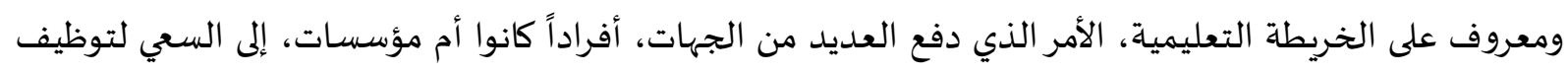
الإبداع كجزء لا يتجزأ من اجنداتهم (داود، 2020). 
ممارسات قائد المدرسة في تعزيزثقافة الإبداع لدى المعلمين:

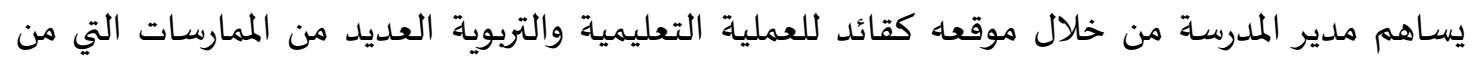
شأنها أن تحسن جودة الأداء المدرسي وتسهه في تطور المدرسة ودفعها نحو التميز والارتقاء بذاتها وبمعلميها وطلبتها،

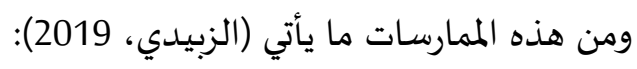

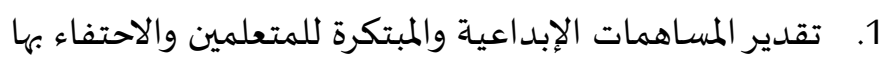

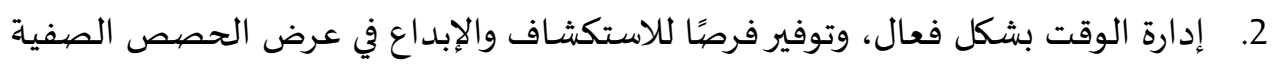

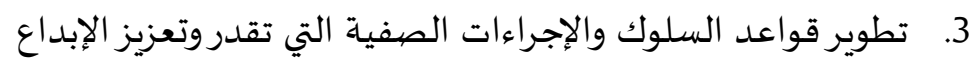

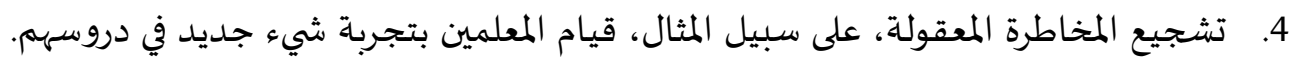

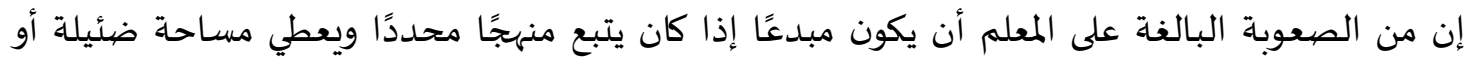

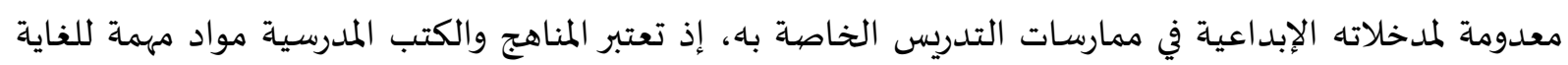

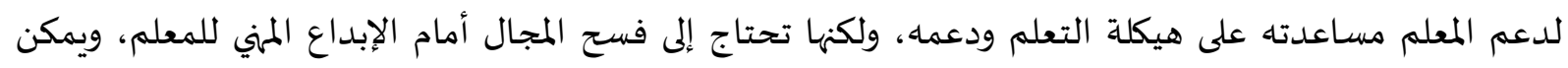

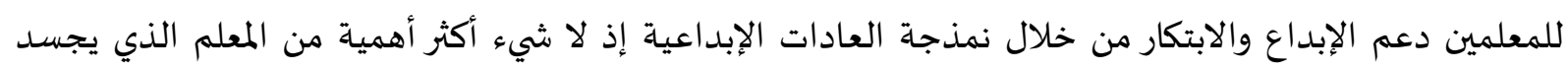

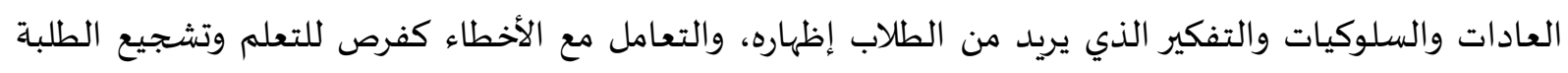

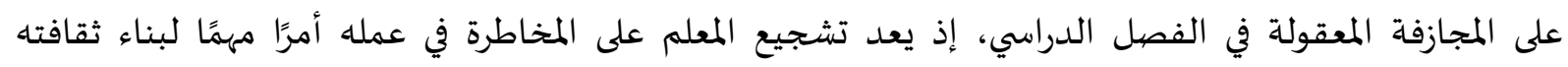
الإبداعية، من المهم أن يتم ذلك في بيئة داعمة من الإدارة وصناع القرار التربويين (Yossef \& Rakha, 2017).

ثانياً - الدراسـات السابقة: فيما يلي عرضاً للدراسات السابقة العربية والأجنبية المرتبطة بموضوع الدراسة مرتبطة وفقاً لتسلسلها الزمني من الأحدث إلى الأقدم على النحو لـالى الآتي: - أجرت الضمور وآخرون (2021) دراسة هدفت للتعرف على الإدارة بالتحفيز وعلاقتها بالأداء الوظيفي

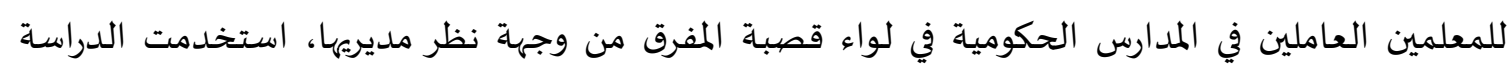

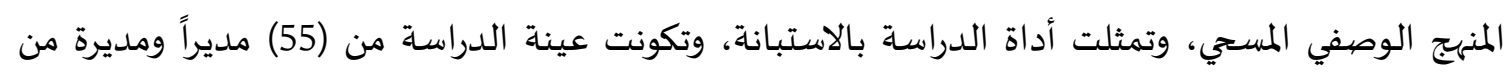

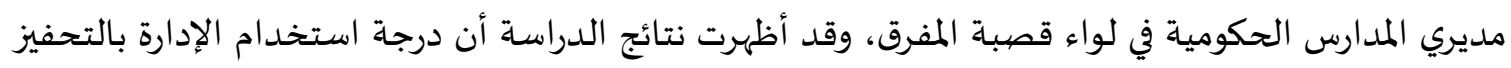

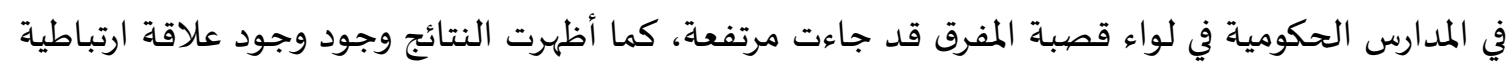

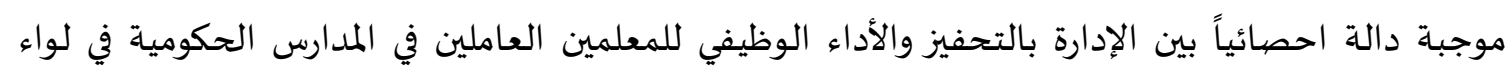
قصببة المفرق من وجهة نظر مدير دوالها. - كما قام أجميل (2020) بدراسة هدفت التعرف إلى واقع تطبيق الإدارة الالكترونية في مدارس الوسط العربي

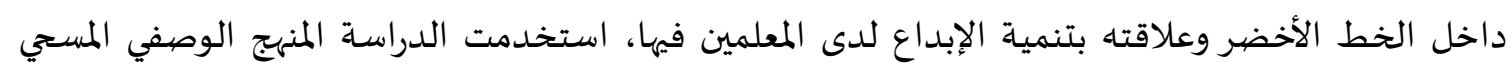

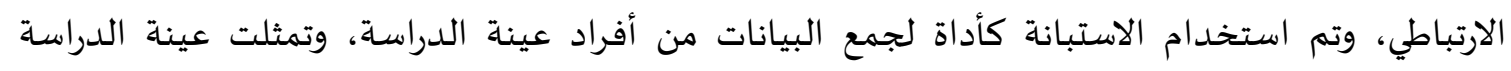

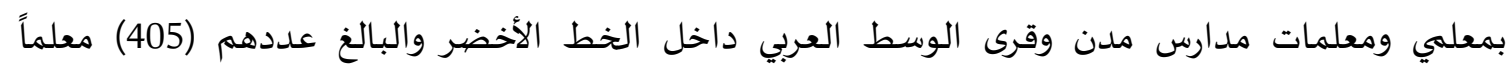

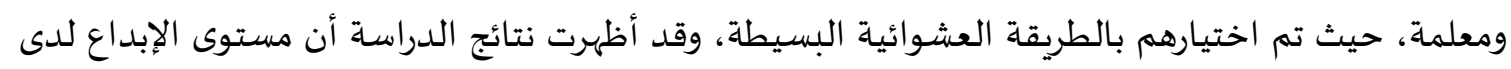

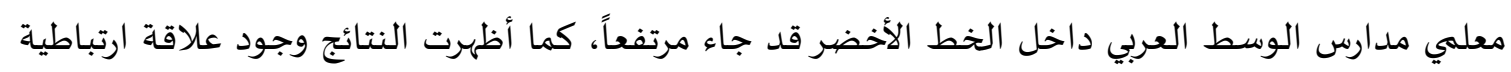

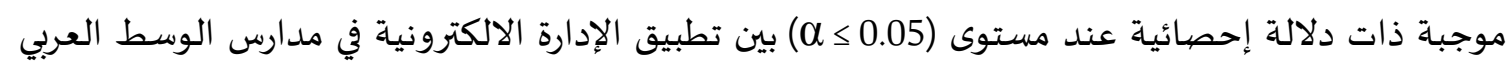

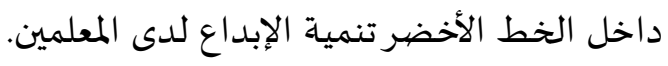


وقامت أبو سنينة (2020) بدراسـة هدفت للتعرف على درجة ممارسة القيادة بالتحفيز لدى مديري المدارس

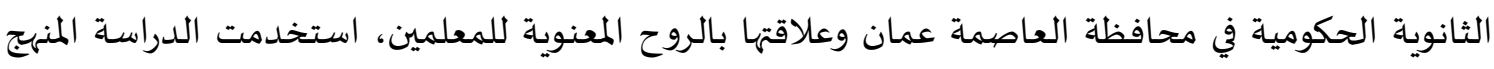

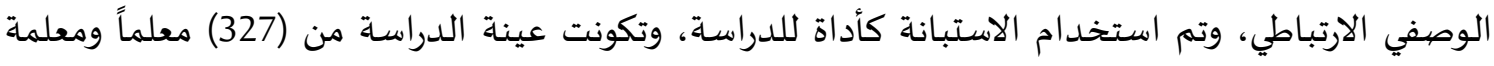

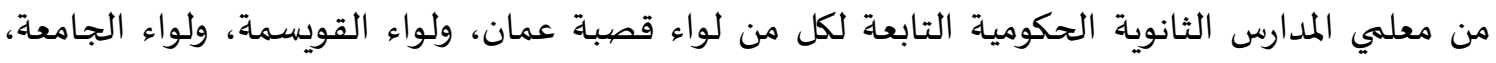

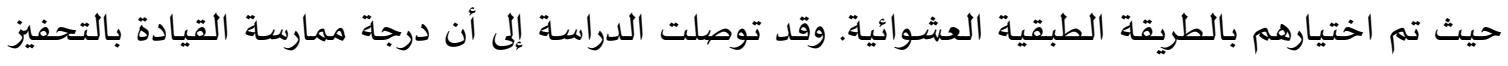

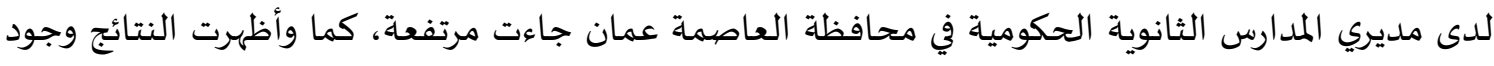
علاقة ارتباطية موجبة بين درجة ممارسة مديري المدارس الثانوية الحكومية في محافظة العاصيمة عمان للقيادة بالتحفيزومستوى الروح المعنوية لدى المعلمين. وأجرى كل من شودري وآخرون (Chaudhry et al, 2020) دراسة هدفت الكشف عن دور الاستراتيجيات

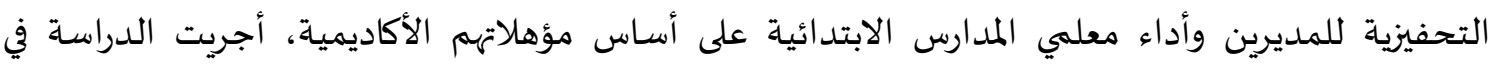

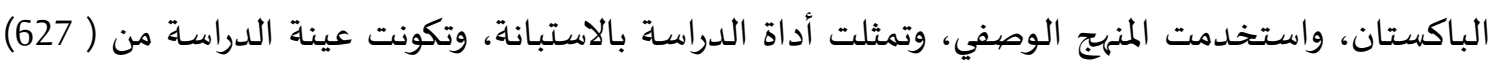

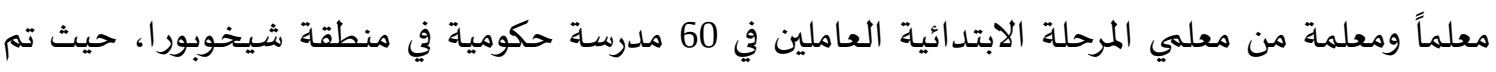

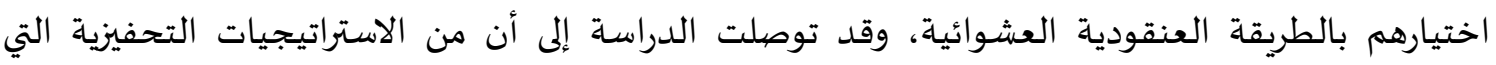

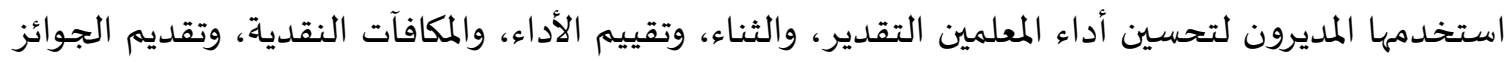

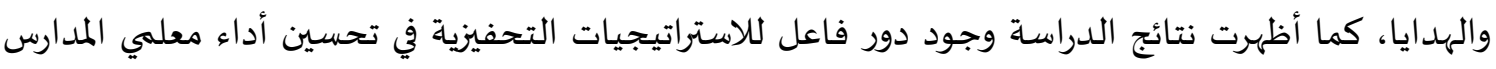
الابتدائية بمختلف مؤهلاتهم الأكاديمية. كما أجرت قزامل (2019) دراسة هدفت للتعرف على العدالة التنظيمية لدى مديري المدارس الثانوية الدرزية داخل الخط الأخضر- في فلسطين المحتلة- وعلاقتها بالإبداع الوظيفي لدى المعلمين من وجها نظهية نظرهم،

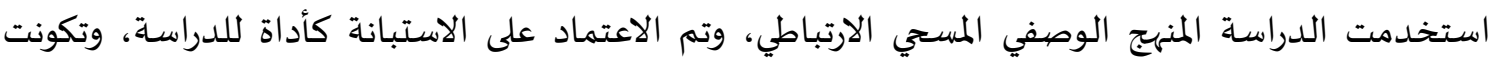

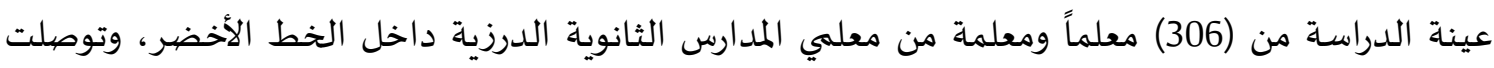

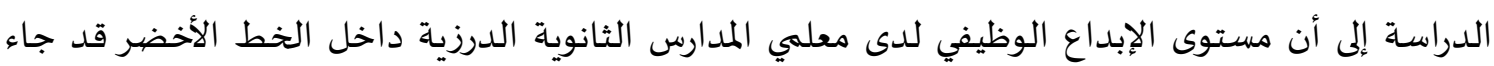

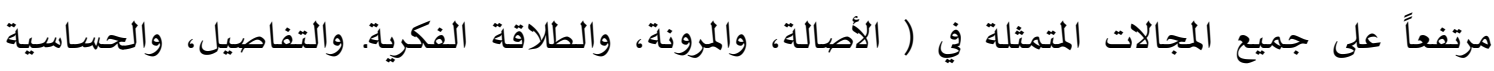
للمشكلات). - مأجرى تيري وآخرون (Terry et al., 2019) دراسة هدفت للتعرف على تأثير المناخ المدرسي التنظيهي على

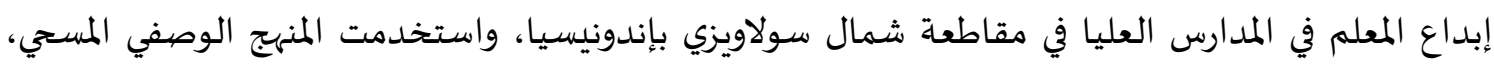

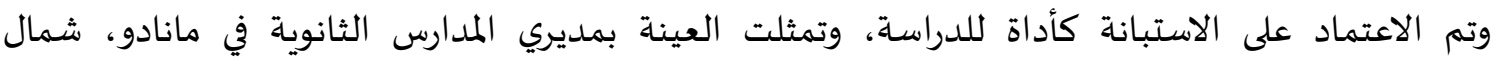

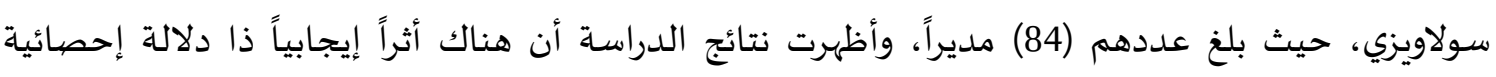

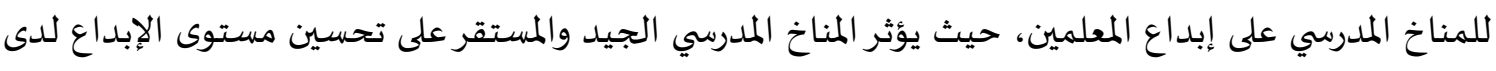
المعلمين وبالتالي تحقيق تفاعل فعّال تعليمي جيد.

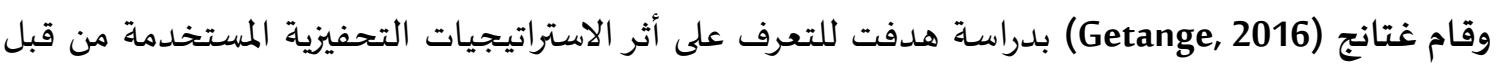

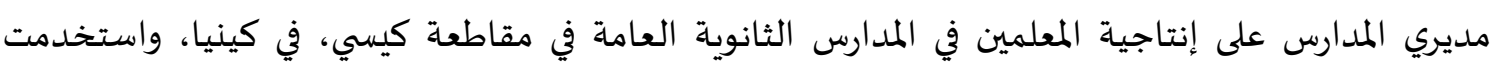

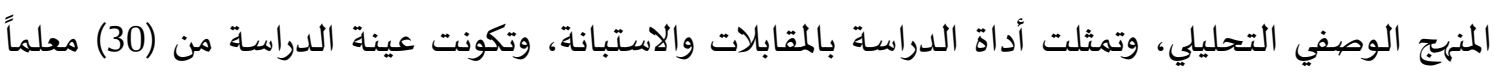

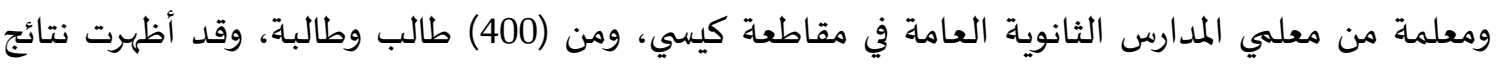

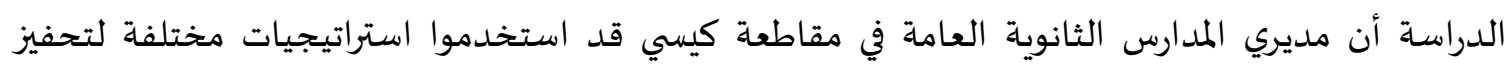

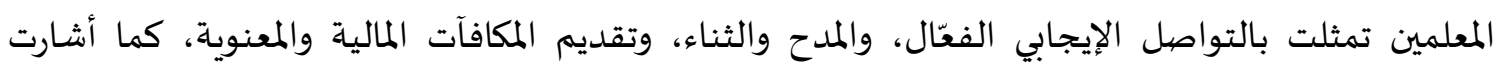


النتائج إلى وجود أثر دال احصائياً للاستراتيجيات التحفيزية التي استخدمها المديرين على إنتاجية المعلمين، حيث تحسنت إنتاجية المعلمين بنسبة (49\%). - قام فيدان وأوزتورك (Fidan \& Oztürk, 2015) بدراسة هدفت إلى التعرف على العلاقة بين مستوى الإبداع

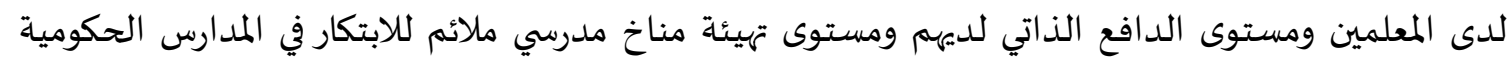
والخاصة في العاصمة التركية أنقرة، واستخدمت المنهج الوصفي المستي الارتباطي، وتم تطوير الاستبانة كأداة

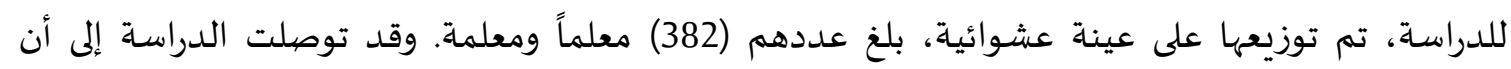

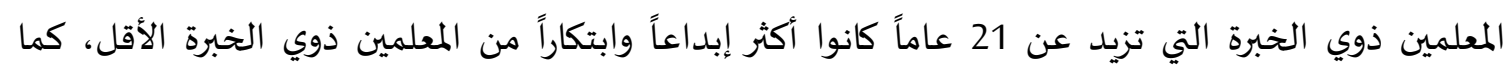

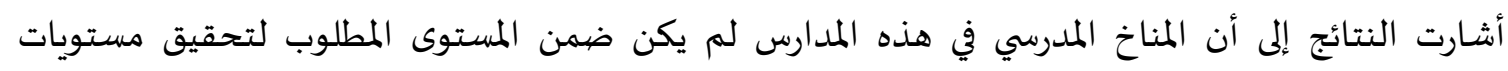

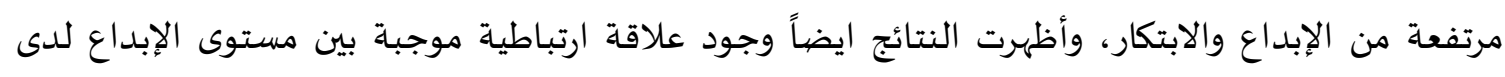

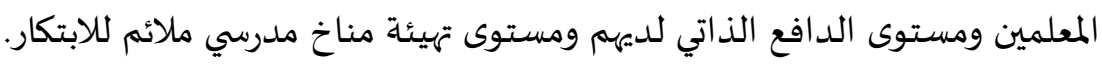

التعليق على الدراسـات السابقة

من خلال الاطلاع على الدراسات السابقة ذات الصلة بموضوات الدهات الدراسة تبين ما يلي:

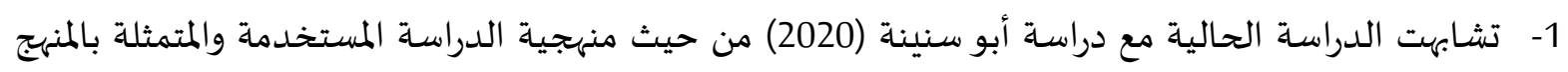

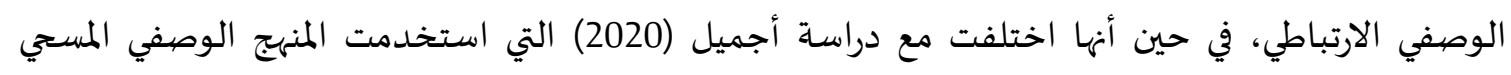
الارتباطي. 2- تشابهت الدراسـة الحالية مع كل من دراسة قزامل (2019)، ودراسة الضمور وآخرون (2021)، ودراسة أبو

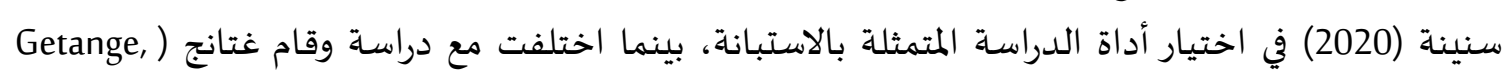
2016) التي استخدمت الاستبانة والمقابلات كأداة للدراسة.

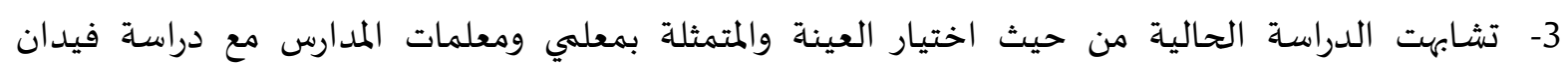

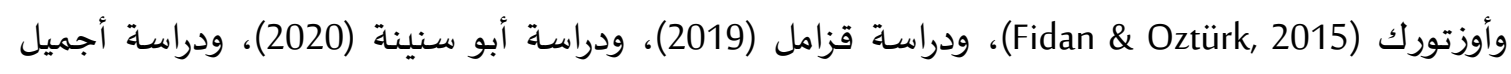

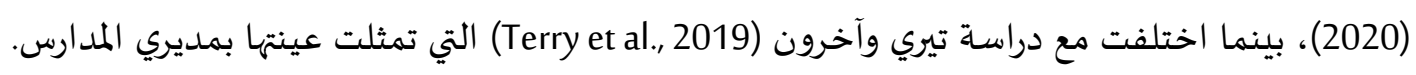

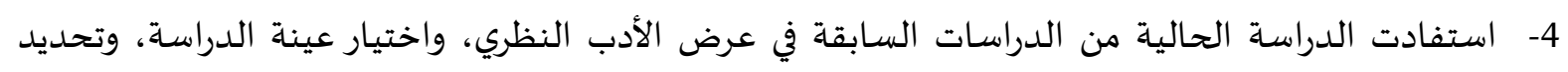

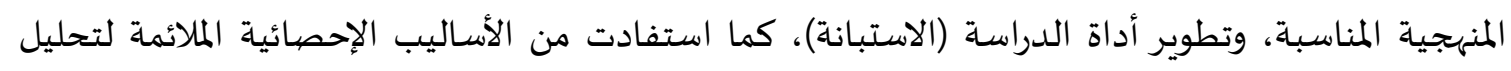
البيانات والوصول إلى النتائج. 5- تميزت الدراسة الحالية بدراستها للعلاقة بين القيادة التحفيزية وتعزيز ثقافة الإبداع لدى المعلمين وهو لم تتطرق اليه أي من الدراسات السابقة.

3- - منهرجية الدراسـة وإجراءاتها.

منهجية الدراسة: استخدمت هذه الدراسة المنهج الوصفي المستي الارتباطي، باعتباره أحد الطرق العلمية لجمع المعلومات بهدف تحليل البيانات الأولية من خلال توزيع أدوات الدراسة على عينة الدراسة الدراسـة. 


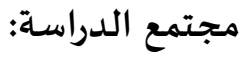

تكون مجتمع الدراسة من جميع المعلمين في المدارس الحكومية بالعاصمة عمان والبالغ عددهم (22977)

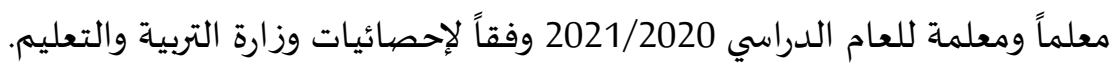

عينة الدراسـة: تم اختيار عينة الدراسة على مرحلتين المرحلة الأولى اختيرت عينة عشوائية عنقودية من لواءين من الألوية

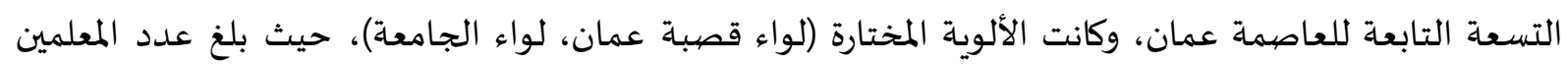

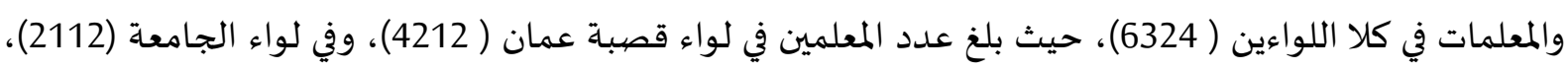

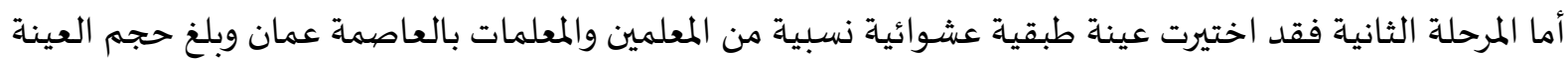

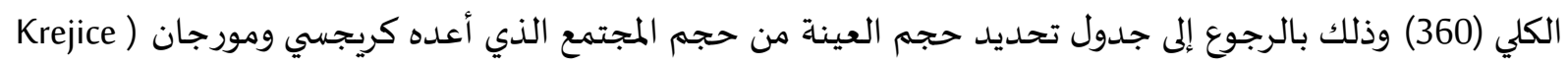

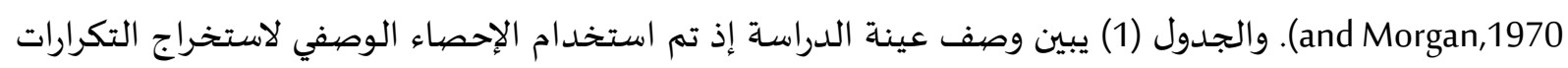
والنسبة المئوية لوصف عينة الدراسـة: واجدول: الجدول (1): توزيع أفراد عينة الدراسة وفقا للمتغيرات الديمغرافية

\begin{tabular}{|c|c|c|c|}
\hline النسبة المئوية & التكرار & الفئة & المتفير \\
\hline 11.1 & 40 & ذكر & \multirow{2}{*}{ الجنس } \\
\hline 88.9 & 320 & أنثى & \\
\hline 72.8 & 262 & بكالوريوس & \multirow{2}{*}{ المؤهل العلهي } \\
\hline 27.2 & 98 & دراسـات عليا & \\
\hline 8.1 & 29 & أقل من 5 سنوات & \multirow{3}{*}{ سنوات الخبرة } \\
\hline 15.0 & 54 & 5- 10 سنوات & \\
\hline 76.9 & 277 & أكثر من 10 سنوات & \\
\hline
\end{tabular}

يتضح من الجدول (1) أن نسبة الذكور من عينة الدراسة (11.1 \%) في حين بلغت نسبة الإناث من عينة

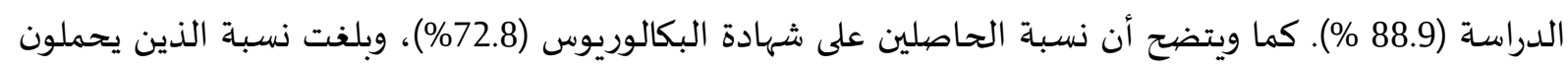

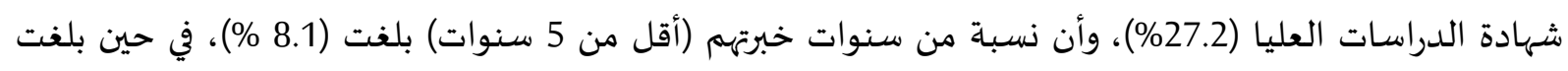

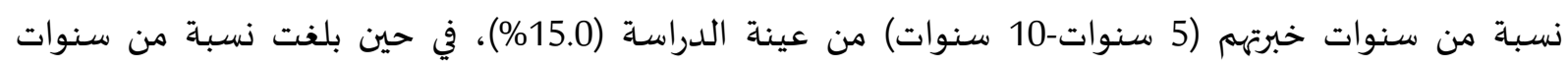

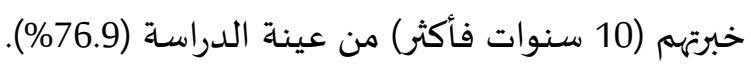

أداة الدراسة:

تمثلت أداة الدراسة بالاستبانة، حيث احتوت على المتغيرات الديمغرافية للعينة، ممثلة في (الجنس، المؤهل

$$
\text { العلمي وسنوات الخبرة)، والمجالات التالية: }
$$

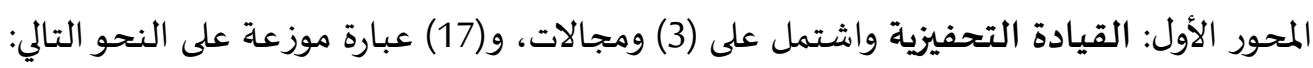

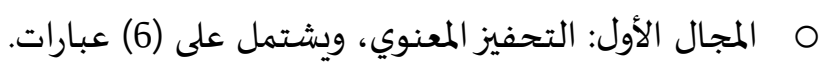

o المجال الثاني: التحفيز الإداري، ويشتمل على (5) عبارات.

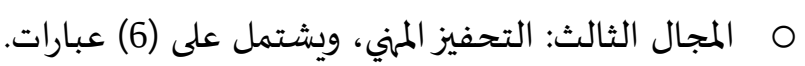


المحور الثاني: ثقافة الإبداع لدى المعلمين واشتمل على (2) مجالين، و(11) عبارة موزعة على النحو التالي:

$$
\begin{aligned}
& \text { O المجال الأول: الأصالة، ويشتمل على (6) عبارات. } \\
& \text { O }
\end{aligned}
$$

صدق أداة الدراسة:

تم التحقق من الصدق الظاهري لأداة الدراسة، وذلك من خلال عرضها على (8) من المحكمين

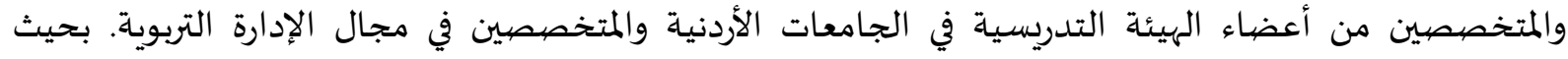
تكونت الاستبانة بصورتها النهائية من (28) عبارة.

ثبات أداة الدراسة تم التأكد من ثبات أداة الدراسة بإجراء اختبار مدى الاتساق الداخلي لعبارات الاستبانة، حيث تم تقييم

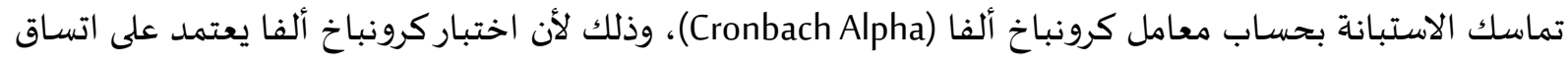

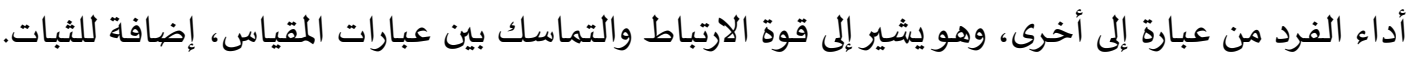

\begin{tabular}{|c|c|c|c|}
\hline 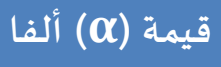 & عدد العبارات & المجال & الرقم \\
\hline 0.813 & 6 & التحفيز المعنوي & 1 \\
\hline 0.806 & 5 & التحفيز الإداري & 2 \\
\hline 0.928 & 6 & التحفيز المهني & 3 \\
\hline 0.783 & 6 & الأصالة & 4 \\
\hline 0.923 & 5 & المرونة & 5 \\
\hline
\end{tabular}
الجدول (2) :معامل ثبات الاتساق الداخلي لأبعاد استبانة الدراسة (كرونباخ ألفار)

وتدل معاملات الثبات كما هي مبينة في الجدول (2) بتميز الأداة بمعامل ثبات قادر على تحقيق أغراض أفرات

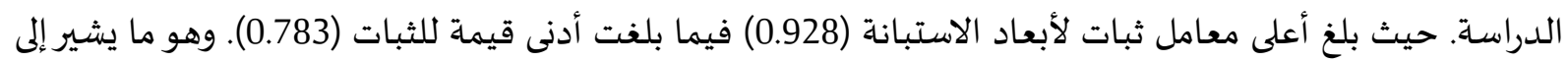

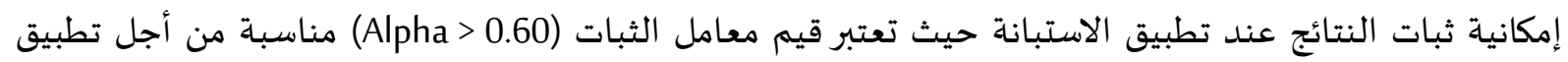
الاستبانة على الدراسـة.

\section{معيار الحكم على النتائج:}

وقد تم استخدام مقياس ليكرت الخماسي حيث تم إعطاء كل عبارة من العبارات الخاصة بكل عبارة من الحن

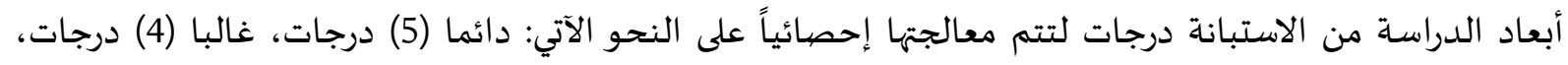

$$
\begin{aligned}
& \text { أحيانا (3) درجات، قليلا (2) درجتان، نادرا (1) درجة واحدة. }
\end{aligned}
$$

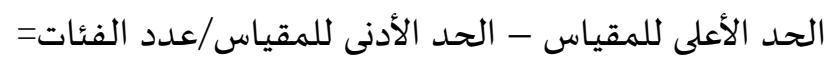

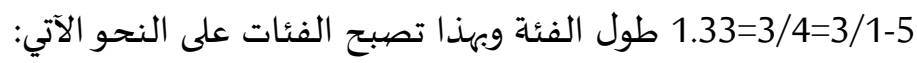

الوسط الحسابي من (1-33) يقابله درجة منخفضية.

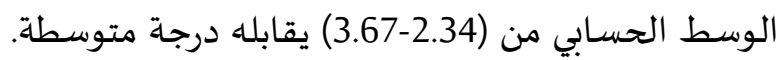

الوسط الحسابي من (3.68-5) يقابله درجة مرتفعة. 


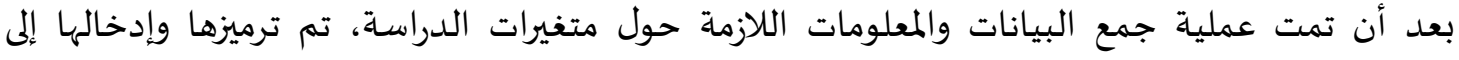

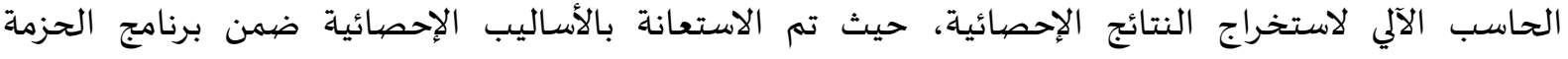

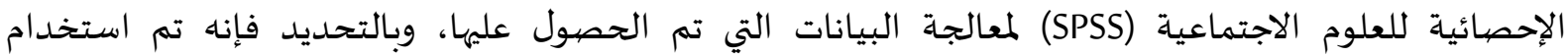
الأساليب الإحصائية الآتية:

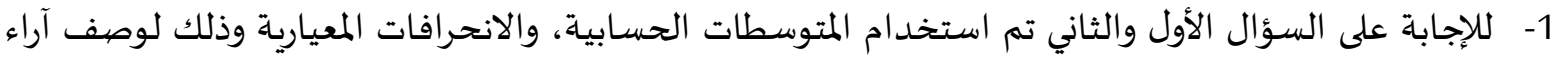
عينة الدراسة حول متغيرات الدراسة، ولتحديد أهمية العبارات الواردة في الاستبانة. 2- للإجابة على السؤال الثالث تم استخدام معامل ارتباط بيرسون (Pearson Correlation) لمعرفة إذا كان هناك

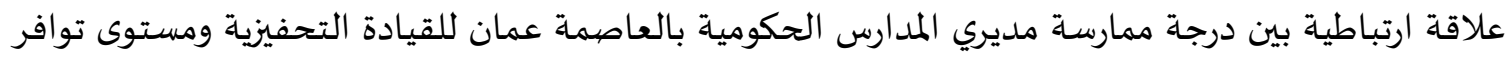
ثقافة الإبداع لدى المعلمين.

4-عرض نتائج الدراسة ومناقشتها.

•النتائج المتعلقة بالسؤال الأول: "ما درجة ممارسة مديري المدارس الحكومية بالعاصمة عمان للقيادة التحفيزية من وجهة نظر المعلمين؟ ولإجابة عن هذا السؤال تم حساب المتوسطات الحسابية والانحرافات المعيارية لمجالات درجة ممارسة

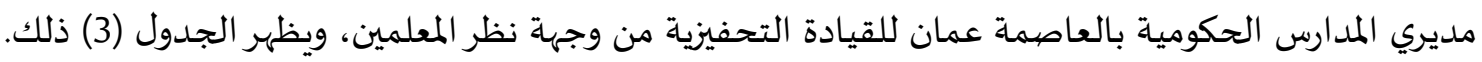

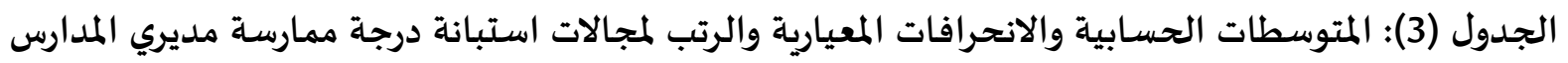

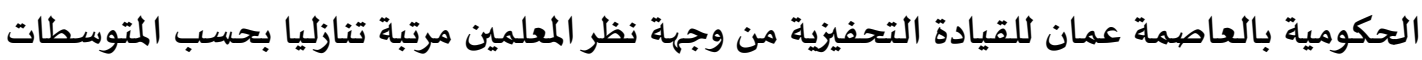

\begin{tabular}{|c|c|c|c|c|c|}
\hline درجة الممارسة & المرتبة & الانحراف المعياري & المتوسط الحسـابي & المجال & الرقم \\
\hline مرتفعة & 1 & 0.94 & 3.98 & التحفيز المهني & 3 \\
\hline مرتفعة & 2 & 0.89 & 3.93 & التحفيز المعنوي & 1 \\
\hline مرتفعة & 3 & 0.85 & 3.67 & التحفيز الإداري & 2 \\
\hline مرتفعة & & 0.82 & 3.86 & \multicolumn{2}{|c|}{ درجة التحفيز } \\
\hline
\end{tabular}

يتبين من الجدول (3) أن درجة ممارسة مديري المدارس الحكومية بالعاصمة عمان للقيادة التحفيزية من

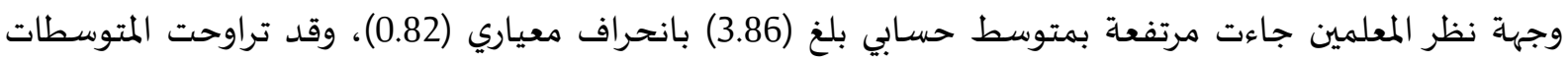

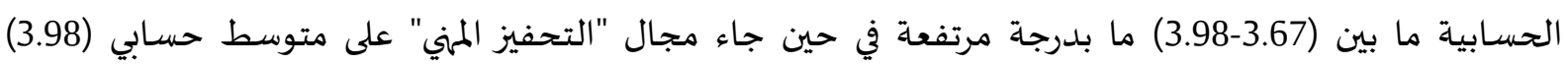

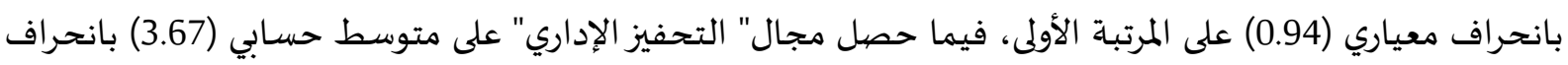

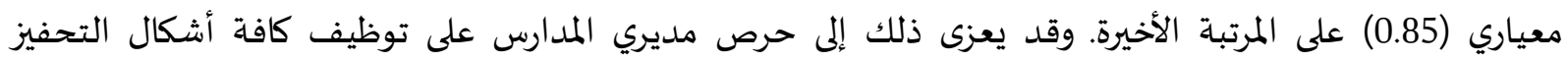

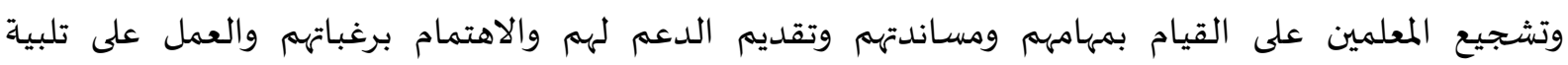

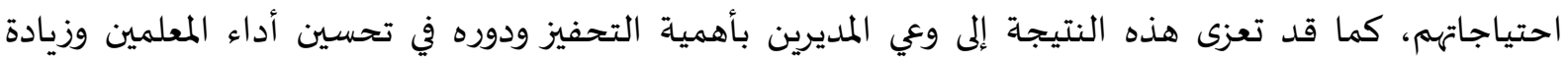

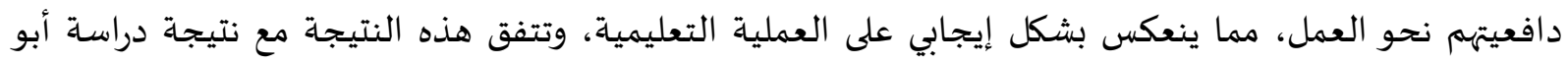

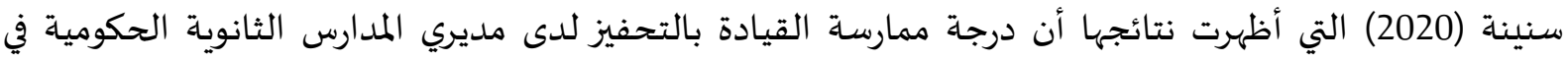


محافظة العاصمة عمان جاءت مرتفعة، كما اتفقت مع نتائج دراسة الضمور وآخرون (2021) التي أظهرت نتائجها

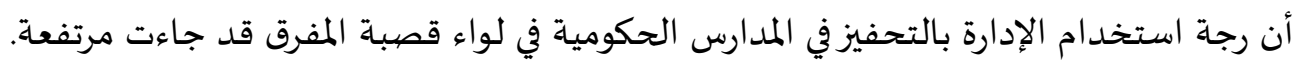
أما بالنسبة لعبارات كل مجال فكانت النتائج على النحو الآتي:

المجال الأول- التحفيز المعنوي:

تم حساب المتوسطات الحسابية والانحرافات المعيارية لجميع العبارات المتعلقة بمجال التحفيز المعنوي كما

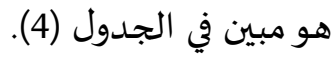

الجدول (4): المتوسطات والانحرافات المعيارية لجميع العبارات المتعلقة بمجال التحفيز المعنوي مرتبة تنازليا

حسب المتوسطات الحسابية

\begin{tabular}{|c|c|c|c|c|c|}
\hline الممارسة & 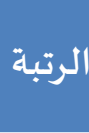 & 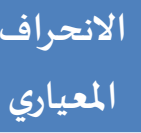 & الحسوسط المبط & 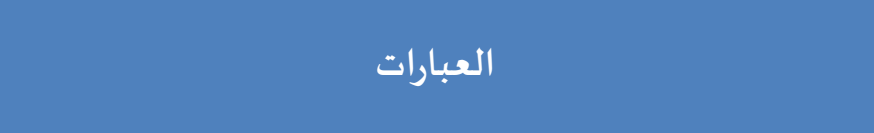 & $\hat{\imath}$ \\
\hline 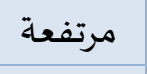 & 1 & 0.94 & 4.05 & يثني مدير المدرسة على الجهود التي يبذلها المعلمون أثناء العمل. & 5 \\
\hline 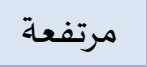 & 2 & 0.98 & 4.00 & ينمي مدير المدرسة لدى المعلمين روح الحماس والانتماء للعمل. & 4 \\
\hline 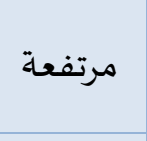 & 3 & 1.02 & 3.99 & 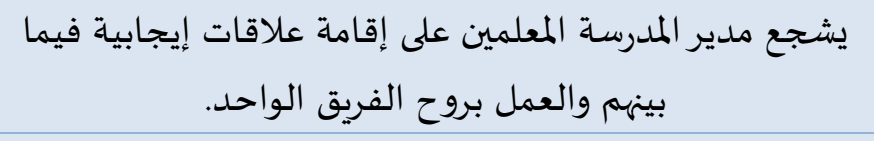 & 2 \\
\hline 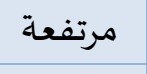 & 4 & 1.02 & 03.9 & يحرص مدير المدرسة على تكريم المعلمين المتميزين. & 1 \\
\hline 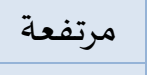 & 5 & 1.1 & 3.83 & يحرص مدير المدرسـة على سماع احتياجات المعلمين وتلبيتها. & 6 \\
\hline 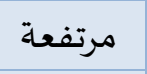 & 6 & 1.08 & 3.82 & يغرس مدير المدرسة لدى المعلمين الثقة بالنفس. & 3 \\
\hline 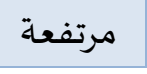 & & 0.89 & 3.93 & المتوسط الكلي للتحفيز المعنوي & \\
\hline
\end{tabular}

تظهر نتائج الجدول (4) المتوسطات والانحرافات المعيارية، حيث تراوحت المتوسطات الحسابية لها بين

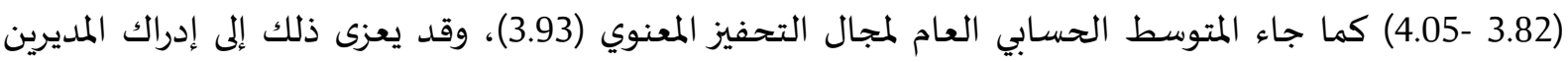

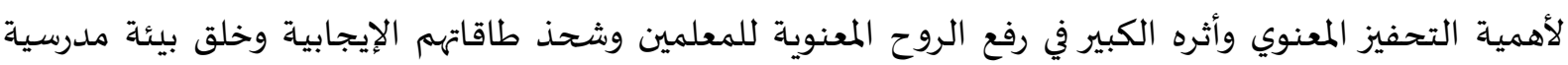

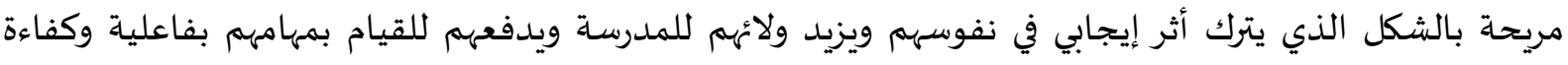
عالية، كما قد يعزى ذلك إلى سعي مديري المدارس الحصول على مستولى مستويات أداء متميزة وإحراز التقدم للمدرسة

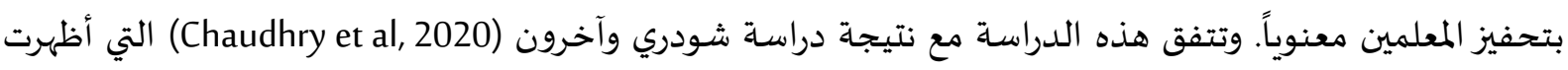

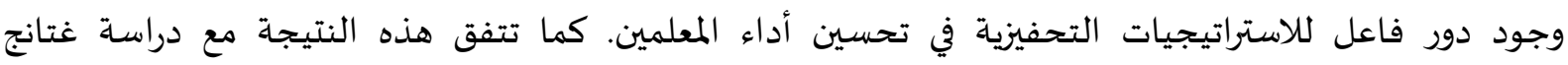
(Getange, 2016) والمدح والثناء، وتقديم المكافآت المعنوية

المجال الثاني- التحفيز الإداري:

تم حساب المتوسطات الحسابية والانحرافات المعيارية لجميع العبارات المتعلقة بمجال التحفيز الإداري كما

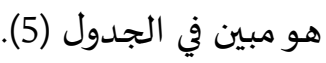


الجدول (5): المتوسطات والانحرافات المعيارية لجميع العبارات المتعلقة بمجال التحفيز الإداري مرتبة تنازليا حسب المتوسطات الحسابية

\begin{tabular}{|c|c|c|c|c|c|}
\hline 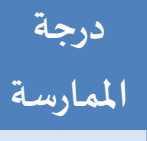 & 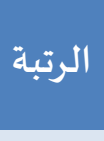 & 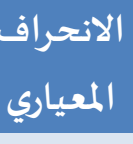 & الحتوسط & 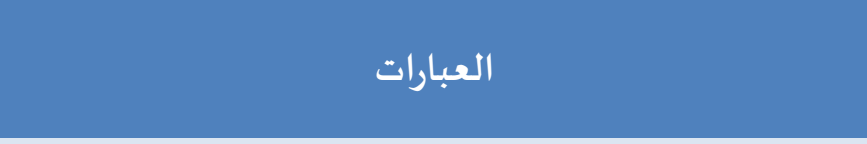 & $\hat{\imath}$ \\
\hline مرتفعة & 1 & 0.86 & 4.19 & يطلع مدير المدرسة المعلمين على المستجدات والقرارات التربوية & 8 \\
\hline 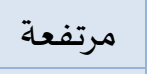 & 2 & 1.07 & 3.68 & يكلف مدير المدرسة المعلمين القيام بمهام إدارية وقيادية. & 9 \\
\hline متوسطة & 3 & 1.09 & 3.53 & يشرك مدير المدرسة المعلمين في حل المشكلات والتحديات & 11 \\
\hline متوسطة & 4 & 1.02 & 3.46 & يحرص مدير المدرسة على جعل المعلمين جزء من عملية صنع & 7 \\
\hline متوسطة & 5 & 1.12 & 3.34 & يفوض مدير المدرسة بعضاً من صلاحياته الإدارية للمعلمين. & 10 \\
\hline مرتفعة & & 0.85 & 3.67 & المتوسط الكلي للتحفيز الإداري & \\
\hline
\end{tabular}

تظهر نتائج الجدول (5) المتوسطات والانحرافات المعيارية، حيث تراوحت المتوسطات الحسابية لها بين

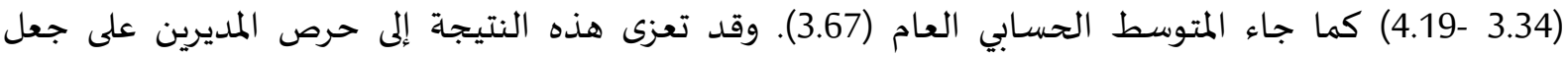

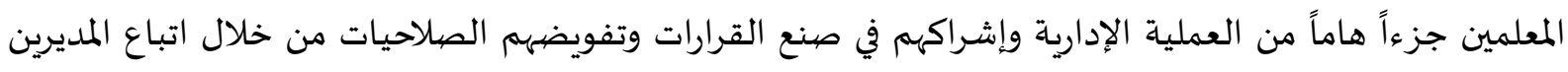

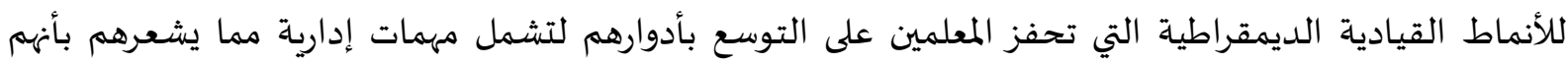

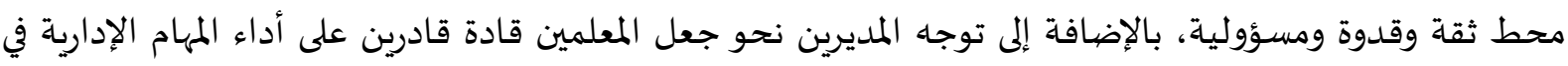
حال غياب أو انشغال مدير المدرسة بالشكل الذي يعتمد باه على المعلمين لأداء المهام الإدارية.

المجال الثالث- التحفيز المني:

تم حساب المتوسطات الحسابية والانحرافات المعيارية لجميع العبارات المتعلقة بمجال التحفيز المهني كما هو

مبين في الجدول (6). الجدول (6): المتوسطات والانحرافات المعيارية لجميع العبارات المتعلقة بمدجال التحفيز المهني مرتبة تنازليا حسب المتوسطات الحسابية

\begin{tabular}{|c|c|c|c|c|c|}
\hline 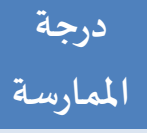 & 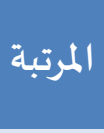 & المعياري - الانحراف & المتوسط & 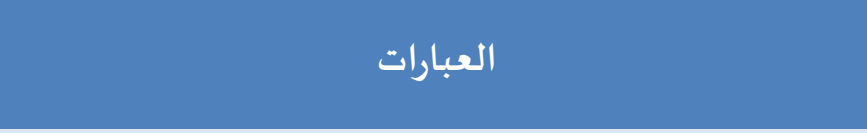 & $\hat{\imath}$ \\
\hline 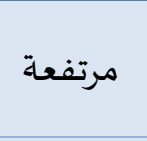 & 1 & 0.94 & 04.2 & يشجع مدير المدرسة المعلمين على الالتحاق بالدورات التدربية داخل المدرسة وخارجها. & 12 \\
\hline 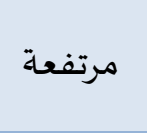 & 2 & 1.02 & 4.09 & يشجع مدير المدرسة المعلمين على استخدام أساليب التدريس & 14 \\
\hline 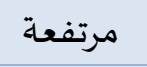 & 3 & 1.01 & 4.02 & يدعم مدير المدرسـة أساليب العمل الجديدة لدى المعلمين. & 15 \\
\hline 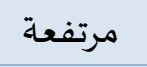 & 4 & 1.01 & 3.94 & يتبنى مدير المدرسة الأفكار الإبداعية لدى المعلمين ويدعمها. & 13 \\
\hline 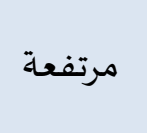 & 5 & 1.08 & 3.89 & يحفز مدير المدرسة المعلمين على التنمية المهنية الذاتية وفق قدراتهم واحتياجاتهم. & 16 \\
\hline
\end{tabular}




\begin{tabular}{|c|c|c|c|c|c|}
\hline 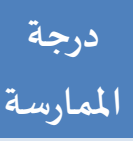 & 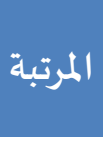 & 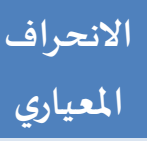 & المتوسط المسابي & 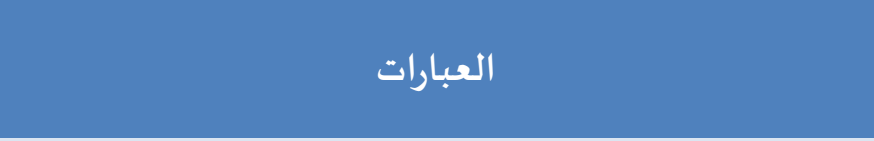 & $\hat{\imath}$ \\
\hline مرتفعة & 6 & 1.2 & 3.74 & ينظم مدير المدرسة الندوات وورش العمل ويشجع المعلمين على حضورها. & 17 \\
\hline 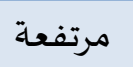 & & 0.94 & 3.98 & المتوسط الكلي للتحفيز المهني & \\
\hline
\end{tabular}

تظهر نتائج الجدول (6) المتوسطات والانحرافات المعيارية، حيث تراوحت المتوسطات الحسابية لها بين

(4.20 3.74) كما جاء المتوسط الحسابي العام (3.98). وقد يعزى ذلك إلى وعي المديرين بأهمية أعداد المعلمين مهنياً وتطوير مهاراتهم واكسابهم الخبرات المختلفة لمواكبة المستجدات التربوية والتعليمياة، والارتقاء بمستوى الأداء المدرسي المبي

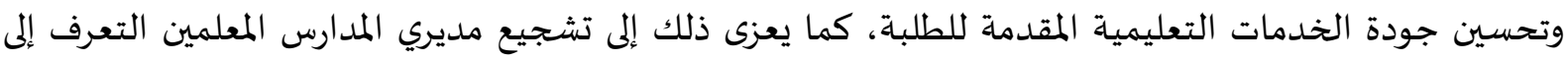

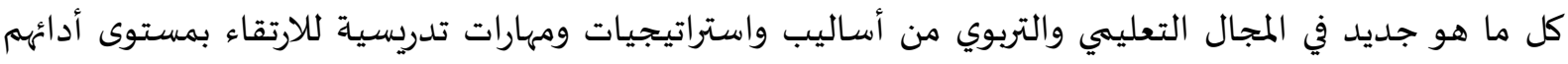

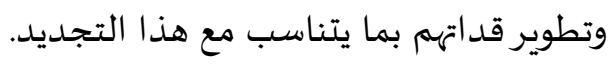

النتائج المتعلقة بالسؤال الثاني: "ما مستوى توافر ثقافة الإبداع لدى المعلمين في المدارس الحكومية بالعاصيمة عمان من وجهة نظرهم؟" ولإجابة عن هذا السؤال تم حسـاب المتوسطات الحسابية والانحرافات المعيارية لمجالات مستوى توافر

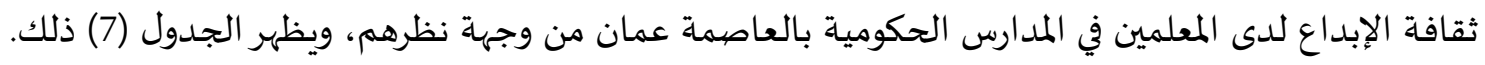

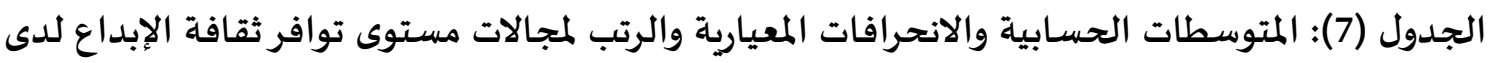

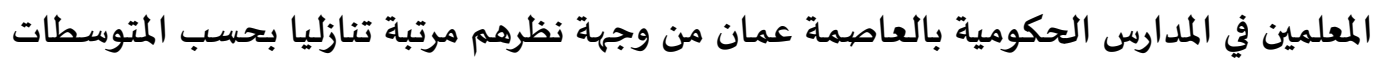

\begin{tabular}{|c|c|c|c|c|c|}
\hline مستوى التوافر & المرتبة & الانحراف & المتوسط الحسابي & المجال & الرقم \\
\hline مرتفع & 1 & 0.58 & 4.25 & المرونة & 2 \\
\hline مرتفع & 2 & 0.64 & 4.08 & الأصـالة & 1 \\
\hline مرتفع & & 0.57 & 4.16 & قافة الإبداع & درجة \\
\hline
\end{tabular}

يتبين من الجدول (7) أن مستوى توافر ثقافة الإبداع لدى المعلمين في المدارس الحكومية بالعاصمة عمان

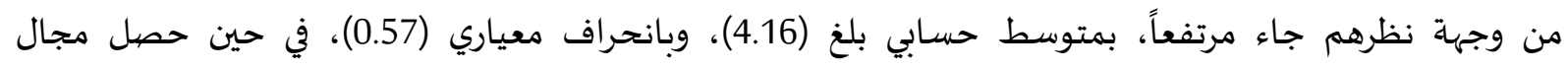

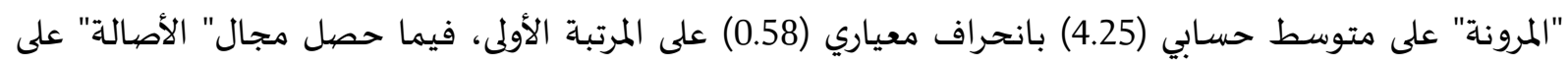

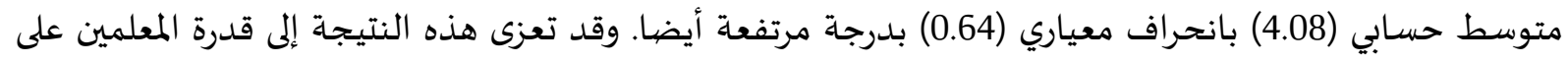

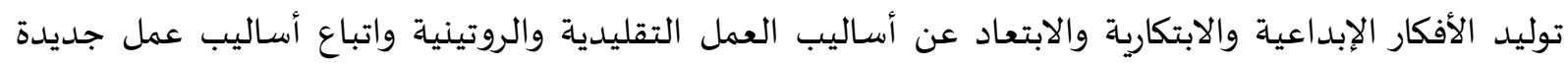

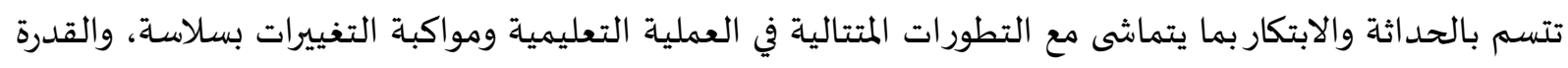
على حل المشكلات والتحديات التي تواجههم بمرونة عالية. وتتفق هذه النتيجة مع نتيجة دراسة أجميل التهاتيل (2020) التي

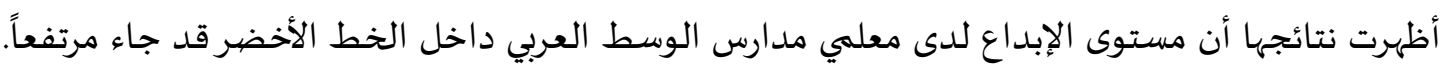

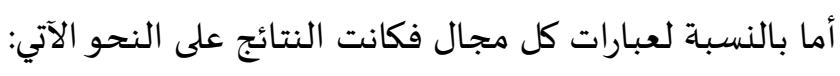

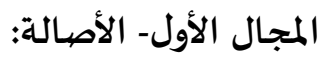

تم حساب المتوسطات والانحرافات لجميع العبارات المتعلقة بمجال الأصالة كما هو مبين في الجدول (8). 
الجدول (8): المتوسطات والانحرافات المعيارية لجميع العبارات المتعلقة بمجال الأصالة مرتبة تنازليا حسب

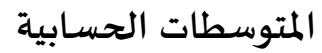

\begin{tabular}{|c|c|c|c|c|c|}
\hline 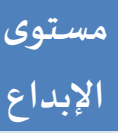 & الرتبة & 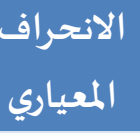 & الحسبط المتوسي & العبارات & $\hat{r}$ \\
\hline مرتفع & 1 & 0.72 & 4.18 & أحاول الخروج عن المألوف في إدارة الموقف التعليمي في الغرفة & 23 \\
\hline مرتفع & 2 & 0.75 & 4.17 & أطور مهاراتي الإبداعية من خلال الاطلاع على كل ما هو جديد في العملية التعليمية. & 22 \\
\hline 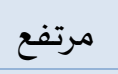 & 3 & 0.79 & 04.1 & أقوم بإثارة الحوار الإبداعي مع زملائي المعلمين. & 21 \\
\hline 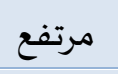 & 4 & 0.73 & 4.06 & ابتعد عن الأسـاليب التدريسية التقليدية والروتينية. & 19 \\
\hline 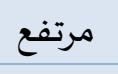 & 5 & 0.77 & 4.00 & استخدم الوسـائل التعليمية المبتكرة والإبداعية. & 20 \\
\hline 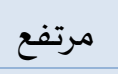 & 6 & 0.88 & 3.96 & أقدم أفكاراً ومقترحات جديدة لتطوير العملية التعليمية. & 18 \\
\hline 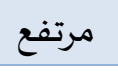 & & 0.64 & 4.08 & المتوسط الكلي للأصالة & \\
\hline
\end{tabular}

تظهر نتائج الجدول (7) المتوسطات والانحرافات المعيارية، حيث تراوحت المتوسطات الحسابية لها بين (3.96 -4.18) كما جاء المتوسط الحسابي العام (4.08). وقد يعزى ذلك إلى توظيف المعلمين للاستراتيجيات والأساليب التعليمية المبتكرة والجديدة وتوليد الأفكار الإبداعية التي تسهم في تطوير العملية التعليمية وتقدمها

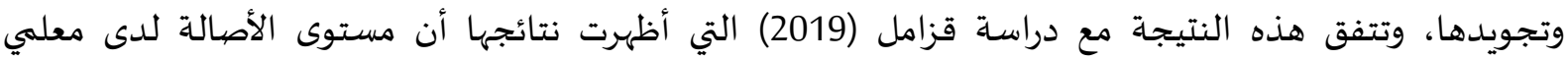

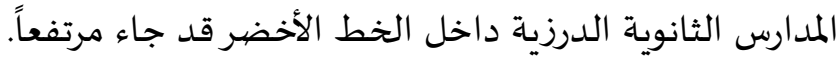

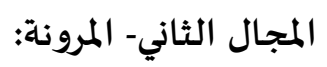

تم حساب المتوسطات والانحرافات لجميع العبارات المتعلقة بمجال المرونة كما هو مبين في الجدول (9).

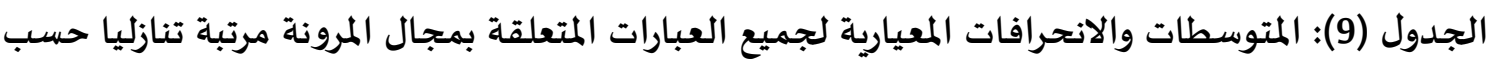

\begin{tabular}{|c|c|c|c|c|c|}
\hline 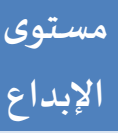 & المرتبة & 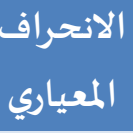 & المتوسط الحسابي & العبارات & $\hat{\imath}$ \\
\hline مرتفع & 1 & 0.69 & 4.29 & أستطيع مواجهة التحديات والصعوبات التي تعترضني بسلاسة & 28 \\
\hline مرتفع & 2 & 0.66 & 4.28 & أحرص على الاستفادة من التخذية الراجعة والملاحظات المقدمة زملائي المعلمين، أو المشرفين أو مدير المدرسة. & 25 \\
\hline مرتفع & 3 & 0.69 & 4.27 & أتقبل النقد البناء الذي يحسن من أدائي ويدفعني لتقديم & 26 \\
\hline 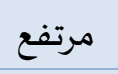 & 4 & 0.67 & 4.25 & أحرص على مواكبة التغييرات والتطورات في العملية التعليمياة. & 27 \\
\hline 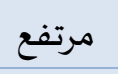 & 5 & 0.73 & 4.14 & أقوم بتجريب الأفكار الجديدة وأتبنى الإيجابي منها. & 24 \\
\hline 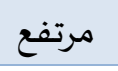 & & 0.58 & 4.25 & المتوسط الكلي للمرونة & \\
\hline
\end{tabular}

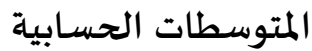


تظهر نتائج الجدول (9) المتوسطات والانحرافات المعيارية، حيث تراوحت المتوسطات الحسابية لها بين (3.4) -4.29) كما جاء المتوسط الحسابي العام (4.25). وقد يعزى ذلك إلى قدرة المعلمين على التعامل مع التغييرات المستمرة في المجال التعليمي ومواكبة التطورات ومواجهة المشكلات والقدرة على حلها، والسعي إلى تحسين أدائهم باستمراروتطبيق الأفكار الجديدة.

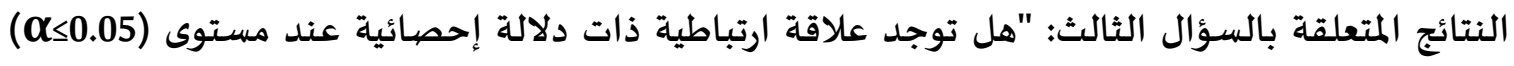
بين درجة ممارسة مديري المدارس الحكومية بالعاصمة عمان للقيادة التحفيزية ومستوى توافر ثقافة

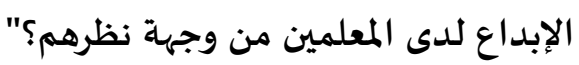
للإجابة عن هذا السؤال قامت الباحثة باستخراج معاملات ارتباط بيرسون (Pearson Correlation) بين كل

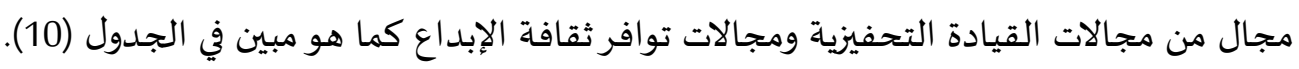

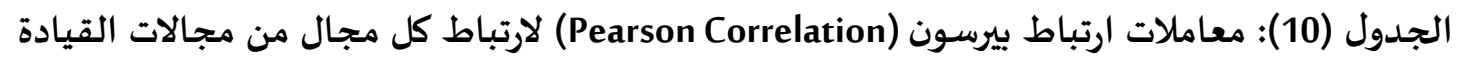

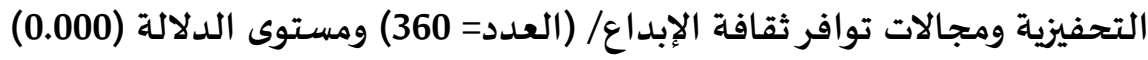

\begin{tabular}{|c|c|c|c|c|}
\hline ثقافة الإبداع & المرونة & الأصالة & المعاملات & المجال \\
\hline $.609^{* *}$ & $.500^{* *}$ & $.527^{* *}$ & معامل الارتباط & التحفيز المعنوي \\
\hline $.502^{* *}$ & $.414^{* *}$ & $.483^{* *}$ & معامل الارتباط & التحفيز الإداري \\
\hline $.601^{* *}$ & $.494^{* *}$ & $.545^{* *}$ & معامل الارتباط & التحفيز المهني \\
\hline $.609^{* *}$ & $.500^{* *}$ & $.527^{* *}$ & معامل الارتباط & القيادة التحفيزية \\
\hline
\end{tabular}

(العدد=360) ومستوى الدلالة (0.000)

يبين الجدول أعلاه مصفوفة معاملات الارتباط بين مجالات الدراسة حيث تبين أن أعلى ارتباط بين

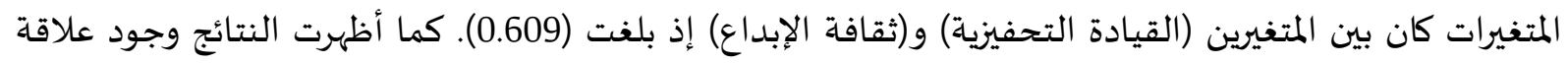

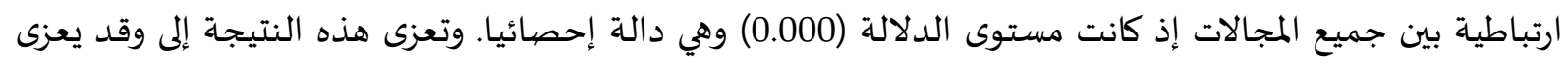

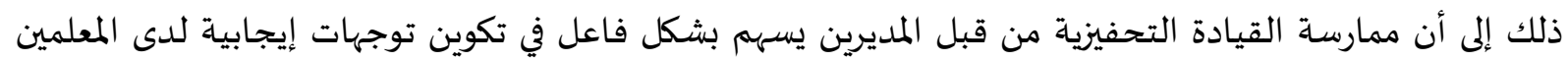

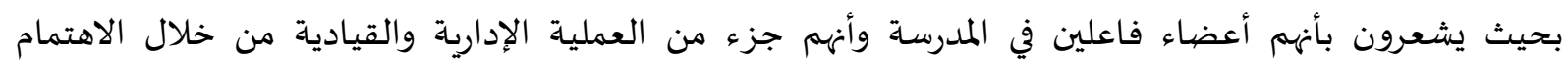

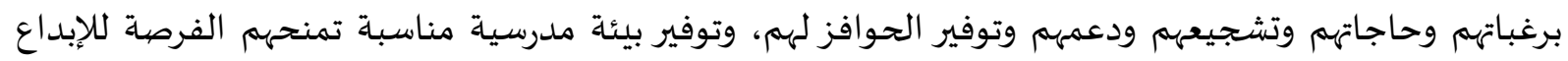

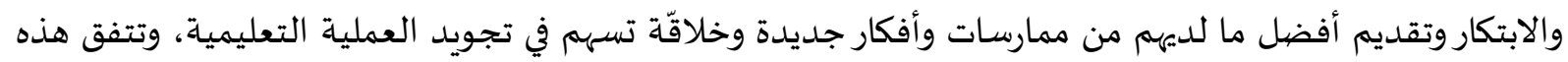

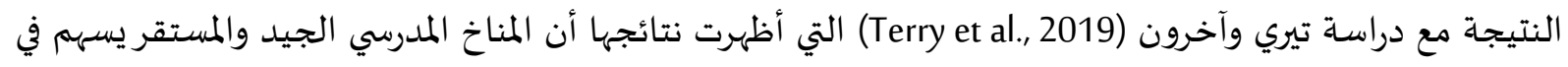

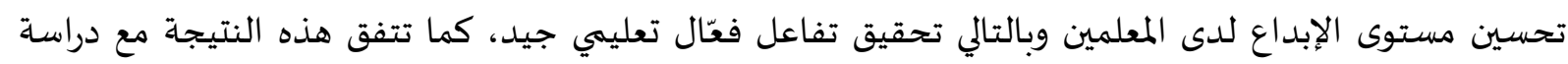

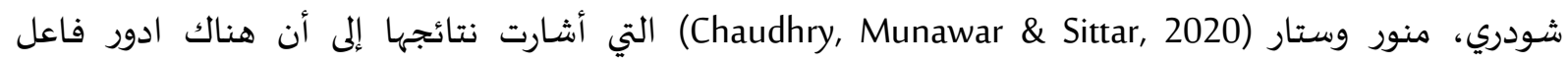
للاستراتيجيات التحفيزية في تحسين أداء معلمي المدارس.

$$
\text { التوصيات والمقترحات }
$$

في ضوء النتائج التي خرجت بها الدراسة توصي الباحثة وتقترح ما يلي:

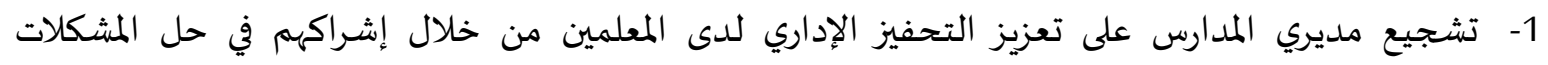
والتحديات الإدارية، وجعلهم جزء من عملية صنع القرار، وتفويضهم الصلاحيات الإدارية. 
2- أن يحرص مديرو المدارس على التحفيز المعنوي من خلال تلبية احتياجات المعلمين والاهتمام برغباتهم وتعزيز ثقتهم بأنفسهم. 3- ضرورة عقد مديري المدارس الندوات والورشات وتشجيع المعلمين على حضهورها لتعزيز النمو المهني لديهم وفق احتياجاتهم وقراتهم. 4- تشجيع مديري المدارس على إيجاد استراتيجيات وأساليب تحفيزية جديدة تسهم في تعزيز الإبداع لدى وفر المعلمين. 5- عقد ورش العمل والمؤتمرات من قبل وزارة التربية والتعليم فيما يخص طرق توظيف التحفيز في القيادة المدرسية وبيان أهميته وانعكاساته على تعزيزثقافة الإبداع لدى المعلمين.

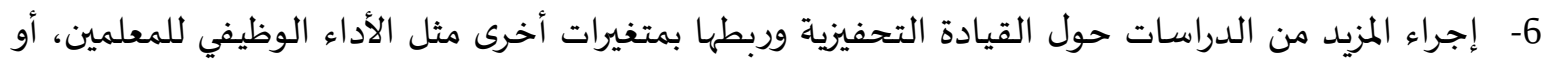
التميز الوظيفي.

- أبو سنينة، رانية (2020). القيادة بالتحفيز لدى مديري المدارس الثانوية الحكومية في محافظة العاصمة عمان

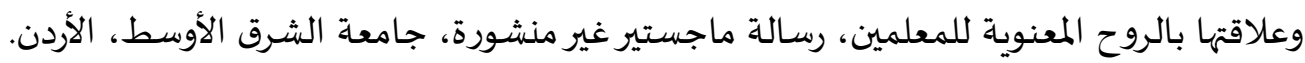

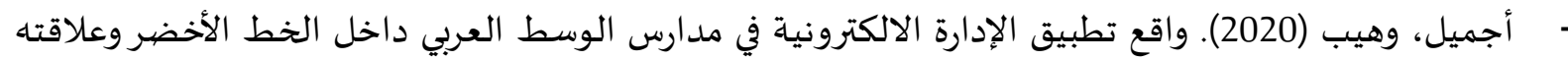

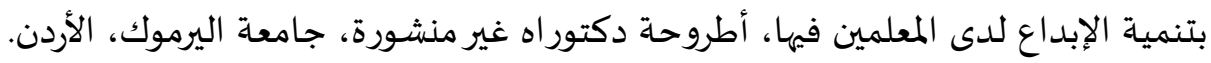
بزبز، محمد؛ أبو الحاج، مجدي (2019). درجة تفعيل الحوافز لدى العاملين في مديريات التربية والتعليم

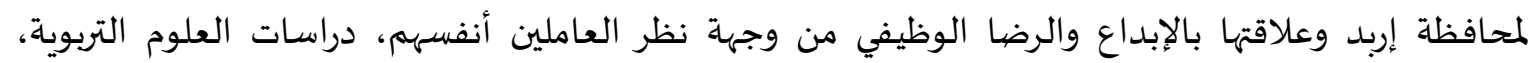
.682-655، (2)46

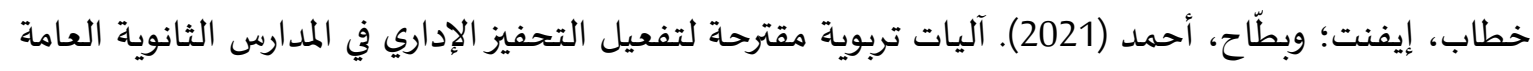

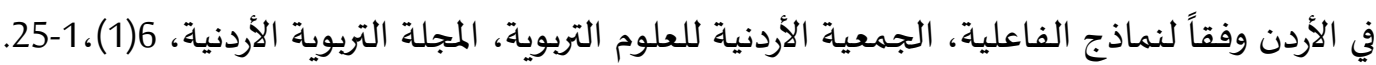
داود، محمد (2020). إدارة التميزوالإبداع الإداري. ط1، عمان: دار ابن النفيس للنشروالتوزيع.

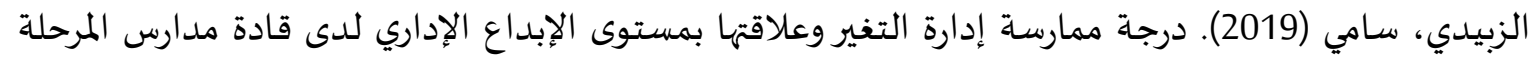

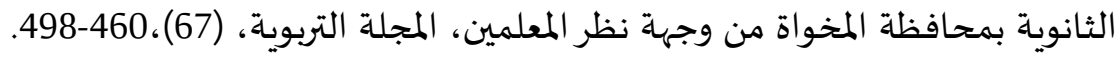
الضمور، هند؛ وبصبوص، شيرين؛ والليمون، كوثر (2021) الإدارة بالتحفيز وعلاقتها بالأداء الوظيفي للمعلمين العاملين في المدارس الحكومية في لواء قصبة المفرق من وجهة نظر مديريها، مجلة دراسات في العلوم الإنسانية والاجتماعية، 4(1)، الفاخوري، سالم (2018). سيكولوجية الإبداع. ط1، عمان: مركز الكتاب الأكاديمي. الفقي، إبراهيم (2011). قوة التحفيز. ط1، القاهرة: ثمرات للنشر والتوزيع.

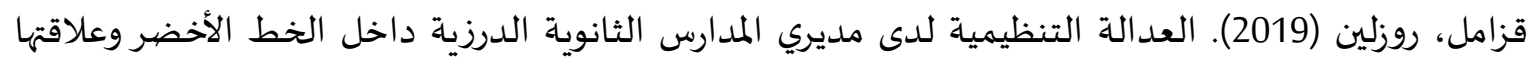
بالإبداع الوظيفي لدى المعلمين من وجهة نظرهم، أطروحة دكتوراه غير منشورة، جامعة اليرموك، الأردن.

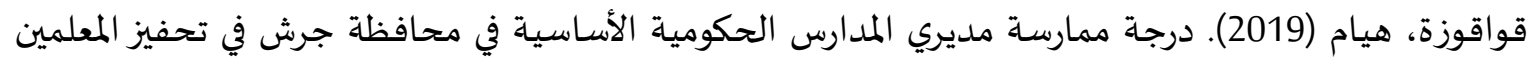
من وجهة نظرهم، رسالة ماجستير غير منشورة، جامعة جرش، درام، الأردن. 
- محمد، محمد؛ والعصيمي، خالد؛ وبرعي، ناهد (2017). التحفيز من منظور إسلامي ودوره في جودة الأداء، مجلة

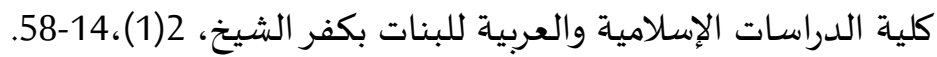

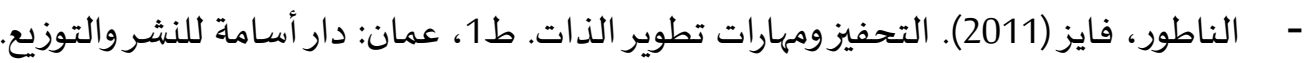

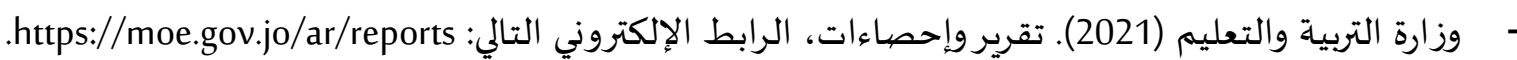

\section{ثانياً- المراجع بالإنجليزية:}

- Abdul-Aal, A. M. A., \& saleh Alshammri, F. (2018). The Reality of Administrative Creativity among the Principals of General Secondary Education Schools a Field Study in Sohag City. Global Journal of Management and Business Research. 18 (13), 16-23.

- Ahmad, F., Abbas, T., Latif, S., \& Rasheed, A. (2014). Impact of transformational leadership on employee motivation in telecommunication sector. Journal of management policies and practices, 2(2), 11- 25 .

- Alawawdeh, S. (2016). The Impact of Creativity Management in Fighting the Educational Crisis in Secondary Schools in Palestine from the Viewpoint of Headmasters. Journal of Education and Practice, 7(11), 98-105.

- Asogwa, V. C., Onah, O., \& Gideon, N. M. (2020). Administrative Strategies for Motivating Teachers and Students of Agricultural Science towards Academic Performance in Senior Secondary Schools in Abia State, Nigeria. International Journal, 6(2), 364-370.

- Bipath, K., \& Nkabinde, M. (2018). The motivational roles of heads of department in learners' performance and quality of schooling in South Africa. South African Journal of Childhood Education, 8(1), 1-8.

- Calvo, C., \& Topa, G. (2019). Leadership and Motivational Climate: The Relationship with Objectives, Commitment, and Satisfaction in Base Soccer Players. Behavioral Sciences, 9(3), 1- 29.

- Chaudhry, A. Q., Munawar, S., \& Sittar, K. (2020). Role of Principals' Motivational Strategies and Performance of Elementary Schools Teachers Regarding their Academic Qualification. Journal of Elementary Education, 29(2), 109-120.

- Fidan, T., \& Oztürk, I. (2015). The relationship of the creativity of public and private school teachers to their intrinsic motivation and the school climate for innovation. Procedia-Social and Behavioral Sciences, 195, 905-914.

- Firza, Y. M., Musa, H., \& Joko, A. (2019). The effect of leadership style, motivation and Discipline of work on the performance of employee of bank XYZ in the JATIWARINGIN area, RJOAS. 3(87), 188-195.

- Getange, K. N. (2016). Motivational strategies and teachers productivity: lessons of experience from public secondary schools in Kisii County, Kenya. IOSR Journal of Research Method, in Education, 6(4), 33-38. 
- Lopez, C. I., \& Grubbström, E. (2018). Motivational factors and Leadership preferences of the Millennial generation: Unlocking the potential of our future leader, Master Thesis, Blekinge Institute of Technology, Sweden.

- Onjoro, V., Arogo, R. B., \& Embeywa, H. E. (2015). Leadership Motivation and Mentoring Can Improve Efficiency of a Classroom Teacher and Workers in Institutions. Journal of Education and Practice, 6(15), 1-14.

- Sutanto, E. (2017). The influence of organizational learning capability and organizational creativity on organizational innovation of Universities in East Java, Indonesia. Asia Pacific Management Review, 22(3), 128-135.

- Terry, H., Umbase, R. S., Pelealu, A. E., Burdam, Y., \& Dasfordate, A. (2018). Teacher creativity and school climate, Advances in Social Science, Education and Humanities Research, 226, 708-710.

- Wibowo, A., \& Saptono, A. (2018). DOES TEACHERS'CREATIVITY IMPACT ON VOCATIONAL STUDENTS'ENTREPRENEURIAL INTENTION?. Journal of Entrepreneurship Education, 21(3), 1-12.

- Yossef, S. \& Rakha, A. (2017). Efficiency of Personal and Administrative Skills for Managerial Leadership on Administrative Creativity at Najran University. Journal of Education and Practice, 8(6), 113-122. 